\title{
Paleoearthquakes of the Düzce fault (North Anatolian Fault Zone): Insights for large surface faulting earthquake recurrence
}

\author{
D. Pantosti, ${ }^{1}$ S. Pucci, ${ }^{1,2}$ N. Palyvos, ${ }^{1}$ P. M. De Martini, ${ }^{1}$ G. D’Addezio, ${ }^{1}$ P. E. F. Collins, ${ }^{3}$
} and C. Zabci ${ }^{4}$

Received 4 August 2006; revised 4 September 2007; accepted 25 September 2007; published 25 January 2008.

[1] The 12 November $1999 M_{w} 7.1$ earthquake ruptured the Düzce segment of the North Anatolian Fault Zone and produced a $\sim 40$-km-long surface rupture. To improve knowledge about earthquake recurrence on this fault, we undertook paleoseismological trench investigations. We found evidence for repeated surface faulting paleoearthquakes predating the 1999 event during the past millennium. Dating was based on radiocarbon, ${ }^{210} \mathrm{~Pb}$ analyses, and archaeological considerations. In addition to the 1999 earthquake, prior surface faulting earthquakes are dated as follows: A.D. 1685-1900 (possibly end of 19th century), A.D. 1495-1700, and A.D. 685-1020 (possibly A.D. 890-1020). The A.D. 967 and A.D. 1878 historical earthquakes are good candidates to have ruptured the Düzce fault correlating with the oldest and penultimate paleoearthquakes. No obvious correlation for the third paleoearthquake (A.D. 1495-1700) exists. These results shows that the Düzce fault considerably participates, along with the parallel Mudurnu fault sections, in the seismogenic deformation taking place along this part of the North Anatolian Fault. Four events since A.D. 685-1020 (possibly A.D. 890-1020) would yield an average recurrence time for the Düzce fault of 330-430 years (possibly 330-

370 years). The three most recent earthquakes, including 1999, occurred within 500 years. Merging results from other paleoseismological studies along the Düzce fault show a consistency of results and yields average recurrence times for the past 2000 years of 320 390 years. Assuming that the 1999 slip ( $2.7 \mathrm{~m}$ average, $5 \mathrm{~m}$ maximum) is representative of the behavior of this fault, the above recurrence times yield a reference figure of fault slip rate in the range $6.9-15.6 \mathrm{~mm} / \mathrm{a}$.

Citation: Pantosti, D., S. Pucci, N. Palyvos, P. M. De Martini, G. D’Addezio, P. E. F. Collins, and C. Zabci (2008), Paleoearthquakes of the Düzce fault (North Anatolian Fault Zone): Insights for large surface faulting earthquake recurrence, J. Geophys. Res., 113, B01309, doi:10.1029/2006JB004679.

\section{Introduction}

[2] The 12 November 1999 a $M_{w} 7.1$ earthquake ruptured the Düzce fault segment of the North Anatolian Fault Zone (NAFZ) (Figure 1a) producing a $\sim 40-\mathrm{km}$-long surface rupture with up to $5 \mathrm{~m}$ of right-lateral offset (2.7 $\mathrm{m}$ average) and up to $2.5 \mathrm{~m}$ of vertical throw [Akyüz et al., 2000, 2002; Pucci et al., 2007a]. This earthquake is considered to have been triggered by the $M_{w} 7.4$ Izmit earthquake that occurred 3 months earlier (17 August) on the next fault segment to the west.

[3] At a regional scale, the Düzce fault is located just west of the Bolu basin, where the NAFZ starts splaying into

\footnotetext{
${ }^{1}$ Sismologia e Tettonofisica, Istituto Nazionale di Geofisica e Vulcanologia, Rome, Italy.

${ }^{2}$ Also at Dipartimento di Scienze della Terra, Università degli studi di Perugia, Perugia, Italy.

${ }^{3}$ School of Engineering and Design, Brunel University, Uxbridge, UK.

${ }^{4}$ Department of Geological Engineering, Faculty of Mines, Istanbul Technical University, Istanbul, Turkey.

Copyright 2008 by the American Geophysical Union. 0148-0227/08/2006JB004679\$09.00
}

two main strands, the Düzce/Karadere to the north and the Mudurnu to the south, to splay again into three major strands in the Marmara Sea (NNAF, CNAF, and SNAF in Figure 1a) [Wong et al., 1995; Armijo et al., 1999; Okay et al., 1999]. The northern and southern strands together accommodate most of the $2-3 \mathrm{~cm} /$ a present-day strain of the NAFZ [Straub et al., 1997; Reilinger et al., 1997, 2000; Ayhan et al., 1999, 2001]. The Mudurnu segment ruptured entirely during the 1957 and 1967 earthquakes, whereas high seismic potential of the Düzce fault was recognized well before 1999 by A. A. Barka and M. Erdik (Site specific fault rupture hazard investigation for the viaduct $\mathrm{n}^{\circ} 1$ and $1 \mathrm{~A}$ of the Gümüşova-Gerede motorway, unpublished report, 1993) that considered this fault the possible source of a near-future earthquake. The Düzce fault has an average E-W trend and a clear geomorphic expression, being the boundary between the Quaternary Düzce and Kaynasli basins to the north and the Paleozoic-Eocene rocks of the Almacik block to the south (Figure 1b). The eastern and western boundaries of the 1999 earthquake rupture appear to be structurally controlled. To the west, the approximately E-W Düzce fault forms a releasing fault junction [e.g., Christie- 


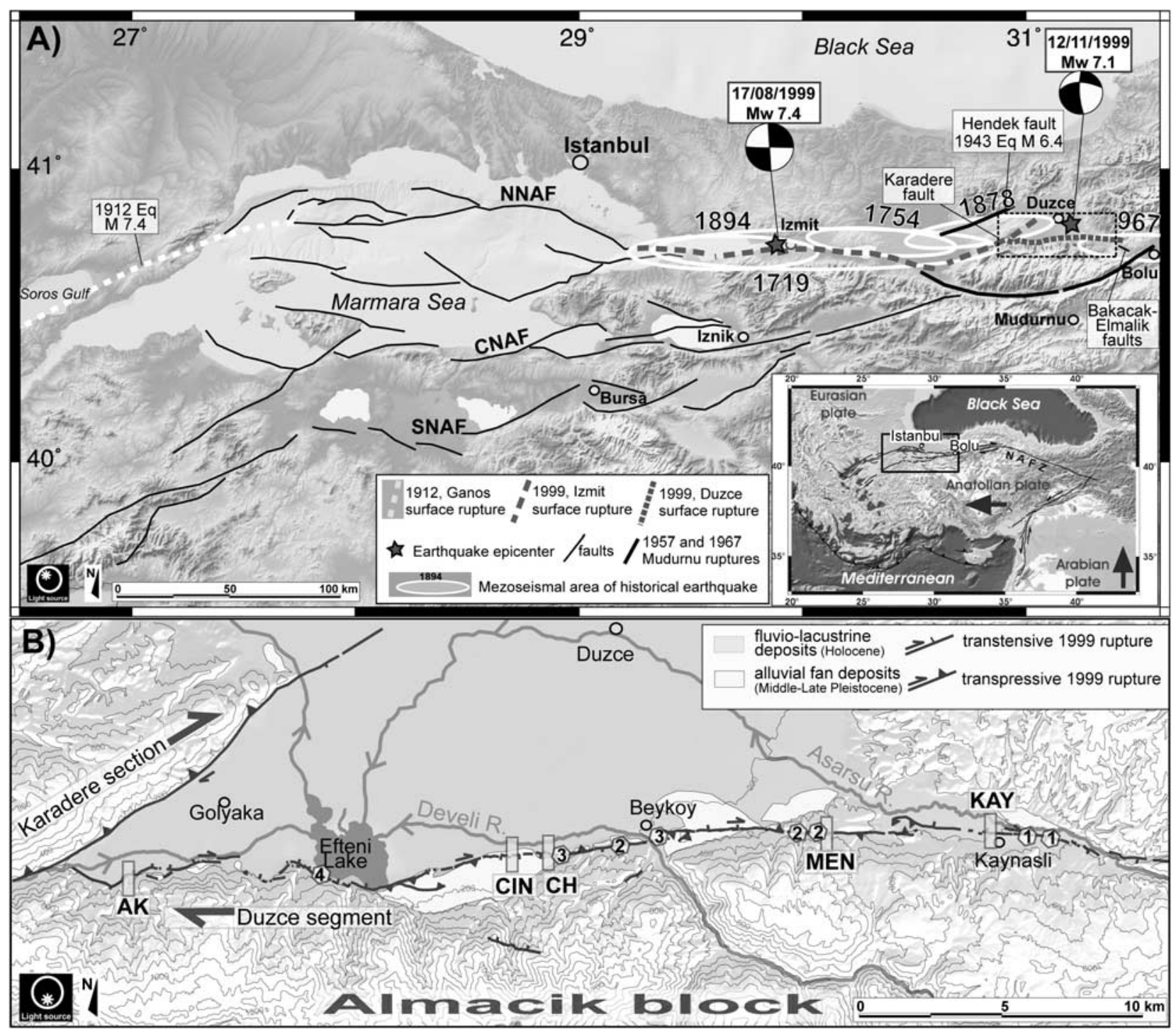

Figure 1. (a) Simplified trace of the North Anatolian Fault Zone west of the Bolu basin (see lower right inset for location of the area). Portions of the fault zone that ruptured during the 1999 earthquakes are shown. The mezoseismal areas of the historical earthquakes occurred near the Düzce fault segment are shown too [from Ambraseys and Finkel, 1995; Ambraseys, 2002; Atakan et al., 2002; King et al., 2001]. NNAF, North Branch of the North Anatolian Fault; CNAF, Central Branch of the North Anatolian Fault; SNAF, Southern Branch of the North Anatolian Fault. (b) Trace of the 1999 surface ruptures along the Düzce fault (see dashed rectangle in Figure 1a for location) and location of the five trench sites discussed in this paper (rectangles; KAY, Kaynasli; MEN, Mengencik; CH, Cakir Haci Ibrahim; CIN, Cinarli; $\mathrm{AK}, \mathrm{Aksu})$. Numbered hexagons are locations where trenching from other authors was performed: 1, Hitchcock et al. [2003]; 2, Komut [2005]; 3, Emre et al. [2001, 2003a, 2003b]; and 4, Sugai et al. [2001]).

Blick and Biddle, 1985] with the NE-SW trending Karadere section [Pucci et al., 2007a], which ruptured during the Izmit earthquake. To the east, the Düzce fault joins the eastern single trace of the NAFZ via an approximately 10 to $15-\mathrm{km}$-wide, right-releasing step over involving the WNW-ESE trending Bakacak and Elmalik faults (Figure 1a) [Altunel et al., 2000; Barka et al., 2001; Hitchcock et al., 2003; A. A. Barka and M. Erdik, Site specific fault rupture hazard investigation for the viaduct $\mathrm{n}^{\circ} 1$ and $1 \mathrm{~A}$ of the Gümüşova-Gerede motorway, unpublished report, 1993].
Both of these step overs appear unfavorable to rupture propagation and possibly represent persistent barriers to earthquake ruptures [Barka and Kadinsky-Cade, 1988; Sibson, 1985; Harris and Day, 1993].

[4] Although Turkey has one of the richer records of historical seismicity in the Mediterranean, no clear evidence for historical earthquakes produced by the Düzce segment of the NAFZ during the past centuries has been found. This is probably due to the scarce density of population and lack of cultural settlements in historical times in the Düzce 
Table 1. Measured and Dendrochronologically Corrected Radiocarbon Ages of Samples Collected in the Düzce Trenches ${ }^{\mathrm{a}}$

\begin{tabular}{|c|c|c|c|c|c|c|}
\hline $\mathrm{Lab}$ & Sample & $\begin{array}{l}\text { Radiocarbon } \\
\text { Age, Ma } \\
\text { B.P. }\end{array}$ & $\delta^{13} \mathrm{C}$ & Calibration & Probability $0.95(2 \sigma)$ & Type of Material \\
\hline Poz-13745 & KW-45 & modern & -27.4 & & & charcoal \\
\hline Poz-13711 & KW-02 & $335 \pm 30$ & -29.8 & A.D. $1475-1640$ & 1.000 & charcoal \\
\hline Beta 201526 & KW-20 & $890 \pm 40$ & -25.5 & A.D. $1035-1220$ & 1.000 & wood \\
\hline Beta 201525 & KE-08 & $1220 \pm 40$ & -23.3 & A.D. $685-890$ & 1.000 & charcoal \\
\hline KIA 22286 & MAN1-W21 & $375 \pm 25$ & -23.97 & $\begin{array}{l}\text { A.D. } 1445-1525 \text {, } \\
\text { A.D. } 1560-1565 \text {, } \\
\text { AD } 1570-1630\end{array}$ & $\begin{array}{l}0.655 ; 0.012 \\
0.334\end{array}$ & charcoal \\
\hline KIA 22285 & MAN5-W20 & $297 \pm 27$ & -26.79 & $\begin{array}{l}\text { A.D. } 1495-1600 \text {, } \\
\text { A.D. } 1615-1655\end{array}$ & $0.717 ; 0.283$ & charcoal \\
\hline KIA 22293 & MAN5-W16 & $801 \pm 27$ & -30.23 & $\begin{array}{l}\text { A.D. } 1185-1200, \\
\text { A.D. } 1205-1275\end{array}$ & $0.038 ; 0.962$ & charcoal \\
\hline KIA 22296 & MAN5-W13 & $1317 \pm 37$ & -25.59 & A.D. $650-770$ & 1.000 & charcoal \\
\hline KIA 22295 & MAN1-W23 & $36 \pm 24$ & -22.87 & $\begin{array}{l}\text { A.D. } 1700-1725 \text {, } \\
\text { A.D. } 1815-1835 \text {, } \\
\text { A.D. } 1880-1915 \text {, } \\
\text { A.D. } 1950-1955^{b}\end{array}$ & $\begin{array}{l}0.131 ; 0.088 ; \\
\quad 0.618 ; 0.164\end{array}$ & charcoal \\
\hline KIA 22288 & MAN6-W18 & modern & -34.79 & - & - & charcoal \\
\hline KIA 22287 & MAN6-W11 & $85 \pm 35$ & -22.53 & $\begin{array}{l}\text { A.D. } 1685-1735 \text {, } \\
\text { A.D. } 1805-1930, \\
\text { A.D. } 1950-1955^{b}\end{array}$ & $0.274 ; 0.713 ; 0.013$ & charcoal \\
\hline KIA 22290 & MAN6-E35 & $200 \pm 25$ & -26.51 & $\begin{array}{l}\text { A.D. } 1650-1685 \text {, } \\
\text { A.D. } 1735-1805 \text {, } \\
\text { A.D. } 1930-1950\end{array}$ & $0.261 ; 0.564 ; 0.175$ & charcoal \\
\hline KIA 22291 & MAN6-E37 & $123 \pm 20$ & -25.97 & $\begin{array}{l}\text { A.D. } 1680-1740 \text {, } \\
\text { A.D. } 1755-1760 \text {, } \\
\text { A.D. } 1800-1895 \text {, } \\
\text { A.D. } 1905-1935 \text {, } \\
\text { A.D. } 1950-1955\end{array}$ & $\begin{array}{l}0.290 ; 0.017 ; 0.541 \\
0.151 ; 0.002\end{array}$ & charcoal \\
\hline Beta 195101 & CH-W01 & $60 \pm 50$ & -24.5 & $\begin{array}{l}\text { A.D. } 1680-1740, \\
\text { A.D. } 1750-1760, \\
\text { A.D. } 1800-1940, \\
\text { A.D. } 1950-1955^{b}\end{array}$ & $\begin{array}{l}0.266 ; 0.013 \\
0.698 ; 0.023\end{array}$ & wood \\
\hline Beta 201522 & CH-W02 & $240 \pm 60$ & -25.6 & $\begin{array}{l}\text { A.D. } 1480-1700 \text {, } \\
\text { A.D. } 1720-1820 \text {, } \\
\text { A.D. } 1830-1880 \text {, } \\
\text { A.D. } 1920-1950\end{array}$ & $\begin{array}{r}0.573 ; 0.294 \\
0.038 ; 0.095\end{array}$ & wood \\
\hline Beta 201523 & CH-W07 & $300 \pm 40$ & -25.3 & A.D. $1475-1660$ & 1.000 & charcoal \\
\hline Beta 195103 & CIN1-W500 & $630 \pm 60$ & -26.9 & A.D. $1280-1420$ & 1.000 & wood \\
\hline Beta 195102 & CIN1-W310 & $980 \pm 40$ & -27.1 & A.D. $990-1155$ & 1.000 & wood \\
\hline KIA 22294 & CIN1-W16 & $112 \pm 42$ & -30.85 & $\begin{array}{l}\text { A.D. } 1675-1770 \text {, } \\
\text { A.D. } 1770-1775 \text {, } \\
\text { A.D. } 1800-1940 \text {, } \\
\text { AD1950-1955 }\end{array}$ & $\begin{array}{l}0.343 ; 0.010 \\
0.638 ; 0.008\end{array}$ & charcoal \\
\hline KIA 22292 & CIN1-W03 & $690 \pm 28$ & -25.59 & $\begin{array}{l}\text { A.D. } 1270-1310, \\
\text { A.D. } 1360-1385\end{array}$ & $0.736 ; 0.264$ & charcoal \\
\hline Beta 201519 & AK-W06 & $1080 \pm 40$ & -25.1 & A.D. $890-1020$ & 1.000 & charcoal \\
\hline Beta 201520 & AK-W29 & $140 \pm 40$ & -26.2 & $\begin{array}{l}\text { A.D. } 1670-1780 \text {, } \\
\text { A.D. } 1795-1895 \text {, } \\
\text { A.D. } 1905-1955\end{array}$ & $\begin{array}{l}0.448 ; 0.380 \\
0.172\end{array}$ & charcoal \\
\hline
\end{tabular}

${ }^{\mathrm{a}}$ Calibration program: Calib Rev 5.02 [Stuiver and Reimer, 2005]; calibration data set from Reimer et al. [2004].

${ }^{\mathrm{b}}$ Influence of nuclear testing ${ }^{14} \mathrm{C}$.

region. The only historical earthquakes that are known to be close enough to be potentially associated to the Düzce fault are A.D. 967 , A.D. 1719, A.D. 1754, A.D. 1878, A.D. 1894 [Ambraseys and Finkel, 1995; Ambraseys, 2002, 2006] (Figure 1a). Because historical information is very limited, knowledge about recurrence of large earthquakes on the Düzce fault can be derived only from paleoseismology. Soon after the 1999 earthquakes several paleoseismological investigations were carried out at different locations along the fault (Figure 1b). On the basis of trenching, Hitchcock et al. [2003] (site 1 in Figure 1b) found evidence for three to five paleoearthquakes in the past 2100 years, with a recurrence interval ranging from 300 to 800 years, and the penultimate event occurring about 300 years ago. Komut [2005] recognized six paleoevents since 1750 B.C. with the one prior to 1999 occurring during the past 500 years (sites 2 in Figure 1b). Emre et al. [2001, 2003a, 2003b] found evidence for three paleoearthquakes since A.D. 665 , the oldest and the youngest of which are dated at A.D. $665-1050$ and A.D. 1650-1750, respectively (sites 3 in Figure 1b). Finally, by paleoseismological geoslicing (by a steel dustpan-like sampling box and its shutter plate) and coring investigations, Sugai et al. [2001] developed a surface faulting history for the past 2 millennia at a site in the western part of the fault (site 4 in Figure 1b). Here, these authors recognize four possible/probable paleoearthquakes 
preceding 1999 and suggest an average recurrence time of $4-500$ years.

[5] In the light of what is discussed above, the main objective of this paper is to provide more constraints for the evaluation of earthquake recurrence on the Düzce fault with particular attention to the dating of individual paleoearthquakes. A major goal is the recognition and dating of pre1999 earthquakes and their possible correlation to known historical earthquakes.

[6] This paper presents the results of trenching at five sites performed during the European Union project Reliable Information on Earthquake Faulting (RELIEF). We compare them with results from previous studies, and discuss their implications for the seismic behavior of the Düzce segment of the NAFZ.

\section{Trenching the Düzce Fault}

[7] We excavated a total of 10 trenches at five different sites along the Düzce fault (Figure 1b). High water table and the lack of sites with slow and continuous sedimentation made the site selection and trench interpretation problematic. Because of the type of sediments and sedimentary structures crossed, no piercing points to measure individual or cumulative horizontal coseismic offset were found; thus, in the following, we report only about the seven fault perpendicular trenches. Dating of paleoearthquakes was based both on radiocarbon (AMS) and ${ }^{210} \mathrm{~Pb}$ analyses. Both dating approaches contain uncertainties. All the radiocarbondated samples were dendrochronologically corrected for the $\mathrm{C}^{12} / \mathrm{C}^{14}$ changes in the atmosphere according to Calib Rev 5.02 [Stuiver and Reimer, 2005] (Table 1). We have to take in account that all the samples are charcoal and wood fragments; they thus provide maximum-limiting ages for the hosting layers. Moreover, most of the trenched deposits appear to be younger than 300 years. The past 300 years are a very problematic time interval for radiocarbon dating because of the "radiocarbon plateau" produced by fossil fuel combustion (Suess effect [Bradley, 1985]) and increasing solar activity following the Maunder minimum [Stuiver and Quay, 1980]. As a consequence of this, a precise age cannot be determined because measured radiocarbon ages in the plateau calibrate with almost equal probability to any age within it. For this reason we limited the number of samples for ${ }^{14} \mathrm{C}$ dating from layers within this age range.

[8] In this work we also explored the use of ${ }^{210} \mathrm{~Pb}$ analyses for dating colluvial and marsh deposits, following the method used by Cundy et al. [1998]; ${ }^{210} \mathrm{~Pb}$ derives from the decay of ${ }^{222} \mathrm{Rn}$, and dating is based on the assumption that all the main sources for ${ }^{210} \mathrm{~Pb}$ (in situ, from the atmosphere, and from eroded material in the catchment) can be considered constant through time. If this is true, a near-exponential decline of activity with depth would be expected. Developing a precise geochronology using shortlived radionuclides in depositional settings where sediment texture is very variable and deposition has occurred in pulses is problematic [Cundy and Stewart, 2004]. However, by using the constant rate of supply model [Appleby, 2001] it is possible to derive an approximate chronology that can be used to test the results of ${ }^{14} \mathrm{C}$ dating, and provide a firstorder estimation of age. Furthermore, in this study, it was hypothesized that soil disturbance during a surface faulting earthquake could lead to the remobilization of "old" material. This material would be delivered to the zone of deposition adjacent to the fault scarp either during the earthquake or subsequently, until the disturbed surfaces had restabilized. In the following, we discuss the observations and interpretations from each trench site moving along the fault from east to west.

\subsection{Kaynasli Trench}

[9] The Kaynasli trench (KAY) was excavated across the 1999 rupture in the floodplain of the Asarsu river (KAY, Figure 1b) at the western edge of a sag pond that is artificially drained by a nearby man-made channel. In this area, the dextral and vertical offsets of the 1999 ruptures were $0.7-1.7 \mathrm{~m}$ and $0.3 \mathrm{~m}$, respectively [Akyüz et al., 2000, 2002; Pucci et al., 2007a]. The trench was about $18 \mathrm{~m}$ long and $2 \mathrm{~m}$ deep and exposed a sequence of predominantly fine sediments (silt and clay), with intercalated layers of sand and pebbles. Fluvial gravel was exposed at the bottom of the central part of the trench. A description of all stratigraphic units is given in Figure 2. Four charcoal samples were dated by AMS from units d, e, f, and g (samples KW-45, KW-02, KW-20, KE-08, see Table 1 and Figure 2). They yielded ages ranging from modern to A.D. 685-890.

[10] Two main fault zones were exposed on both walls of the trench ( 1 and 2 in Figures $2 \mathrm{a}$ and $2 \mathrm{~b}$ ). They were composed of several splays, most of which ruptured in 1999. A third fault zone (3 in Figure 2a), that was not activated in 1999, was located in the southern part of the trench and it is also highlighted by a sharp change in color of units $\mathrm{h}$ and $\mathrm{g}$.

[11] In 1999 the rupture reached the surface along at least one of the main branches of fault zones 1 and 2 and was subsequently capped by the postevent unit $\mathrm{b}$ in fault zone 1 .

Figure 2. (a) Simplified log of the main fault zones of the Kaynasli trench (KAY in Figure 1b). Stars indicate event horizons, and triangles are dated charcoal samples (details in Table 1). Stratigraphy units are a, active brown silty soil; b, brown clayey-silty soil with clay patches (post-1999 earthquake deposit); z, clay and sand from underlying layers, injected in 1999 along the fault plane?; c, granular, brown silty soil, organic-rich with sparse pebbles with injected sand and clay from unit $\mathrm{e}$ at the base in the northern end of the trench; $\mathrm{d}$, dark brown clayey-silty soil with injection of sand and clay from unit e; $\mathrm{k}$, big stones in silty clay matrix with layers ( 2 to $4 \mathrm{~cm}$ thick) of silt, clay, and sand at the bottom (interpreted as man-made feature postdating event Kay2); e, laminated fine sand with important oxidation, sand, and fine to medium gravel in silty matrix; f, laminated dark grey fine sand and fine gravel in clayey-silty matrix, lenses of clay, oxidation; $\mathrm{g}$, light grey clay with sparse pebbles, penetration of roots; h, grey clay, fine to medium gravel in clay matrix, coarse pebbly layer at the base, roots penetration; i, medium to coarse pebbles in orange oxidized clay matrix; $\mathrm{m}$, laminated coarse sand to coarse gravel with some silty matrix. Bluish dashed zones refers to coloration due to reduction. (b) View of the west wall of the trench. (c) Detail of fault zone 1 west wall. (d) Detail of fault zone 1 east wall. 

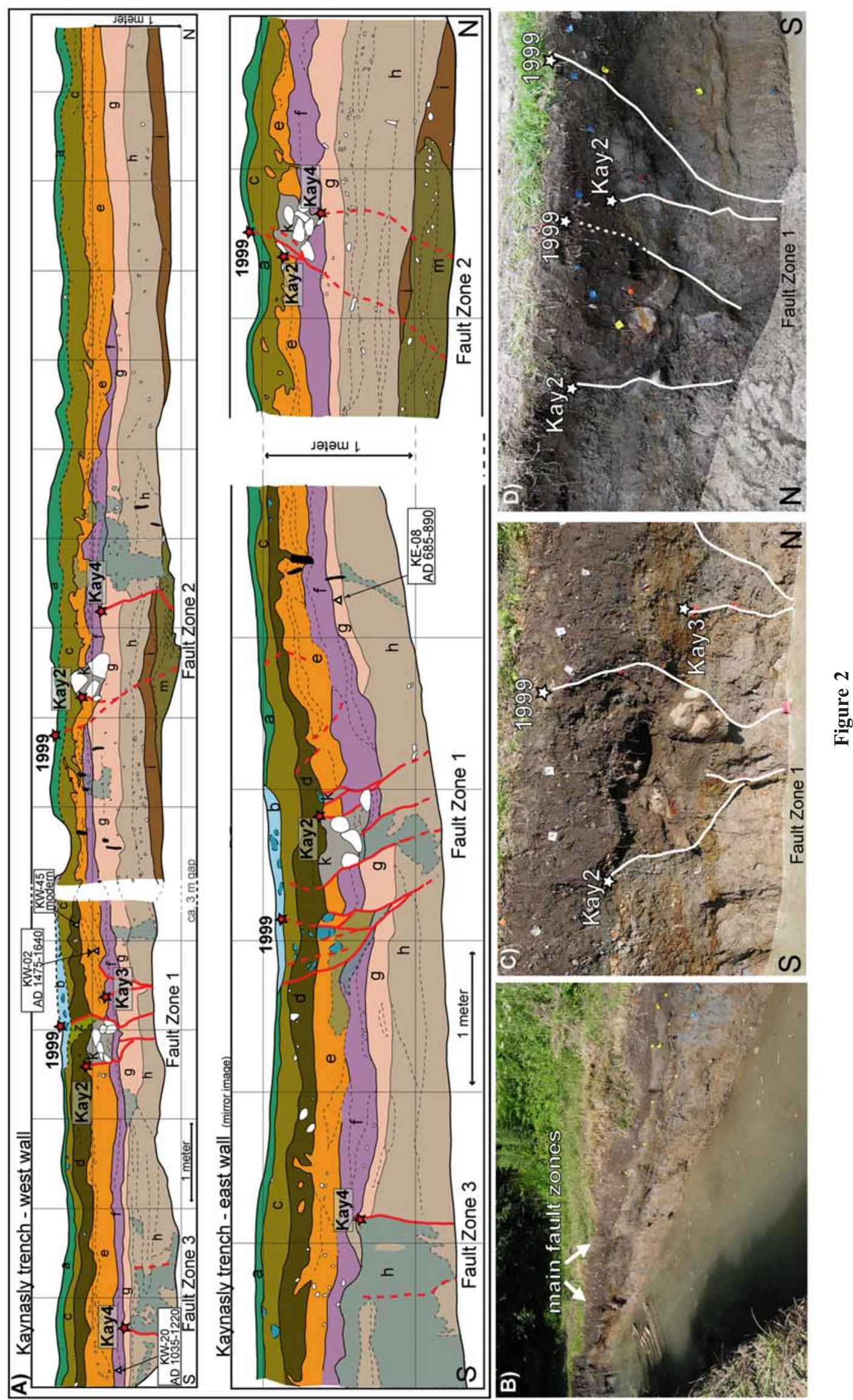

党 

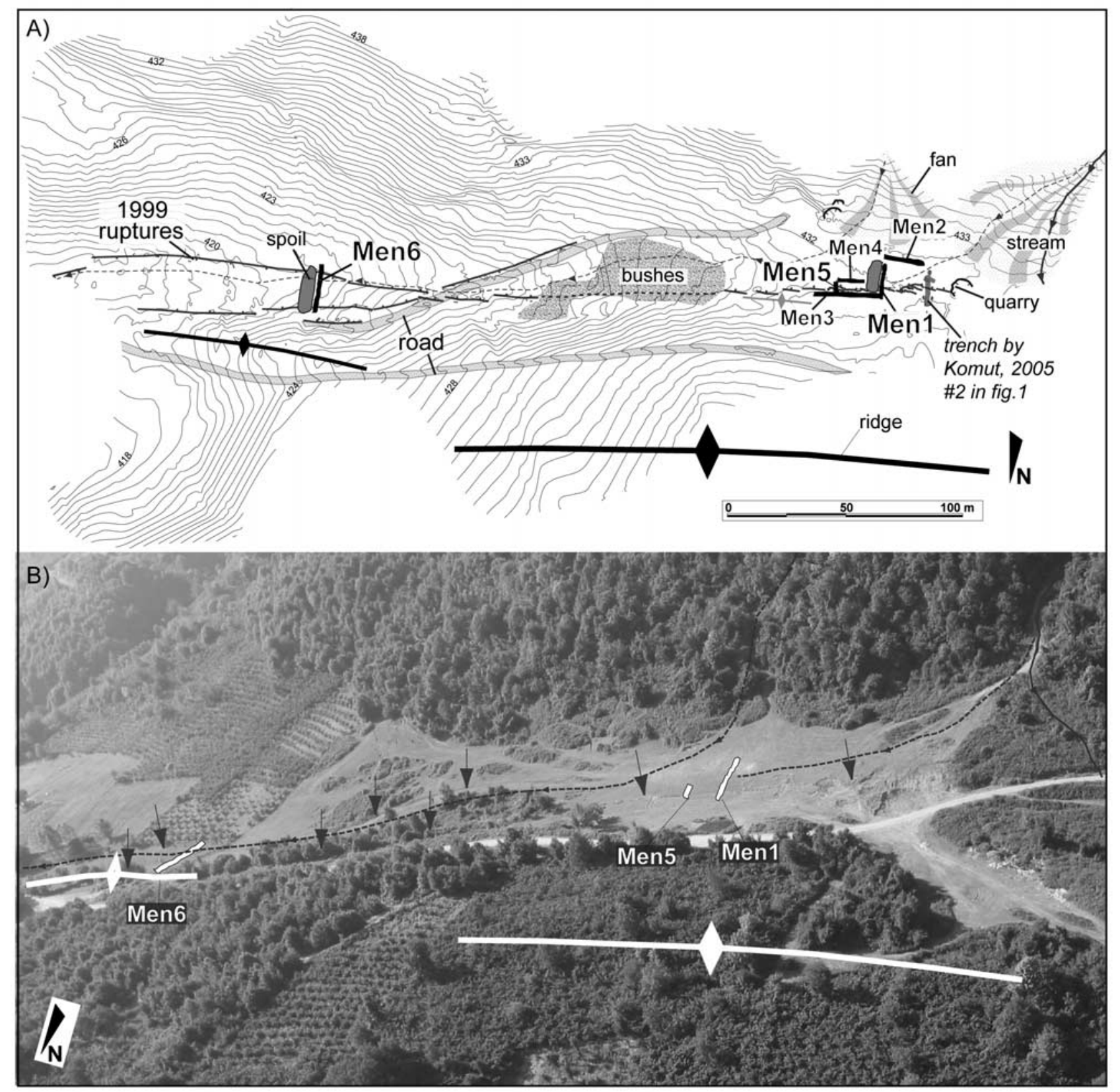

Figure 3. (a) Detailed topographic map of the Mengencik site (MEN site in Figure 1b) obtained by a 5000 point DGPS survey. The trace of the 1999 ruptures is still very clear (thick line with ticks); trenches and main natural and artificial features are shown, and black lines outline tectonic ridges. (b) Aerial view of the site.

During this event, silt and fine sand were injected along the rupture (fault zone 1, west wall, unit $\mathrm{z}$ ) and at the c/e and d/e contacts. On the basis of stratigraphic and structural relations, we find evidence for three surface faulting paleoearthquakes before 1999 (Kay2 to Kay4 in the following and in Figure 2). Evidence for the penultimate earthquake, Kay2, are fault terminations below unit $\mathrm{d}$ as well as the presence in both fault zones of large cobbles and small boulders (unit $\mathrm{k}$ ) completely unrelated to the surrounding stratigraphy and buried by unit d (see also Figures 2c and $2 \mathrm{~d}$ ). These cobbles were likely thrown by local people in the coseismic open fissures and cracks that because of the high water table at the site, were filled by water. This way the cobbles allowed people and herds to cross them. Alteration coatings on the cobbles and boulders of the unit $\mathrm{k}$ and by the presence of laminated fine sediment at the base of channel-like features seem to confirm this hypothesis. The prepenultimate event, Kay3, was recognized only in fault zone 1 of the western wall, where two fault splays deformed the trenched sequence up to unit $f$ and the base of unit e. The top part of unit e has not been affected. Thus we place the event horizon somewhere near the base of unit $\mathrm{e}$. 

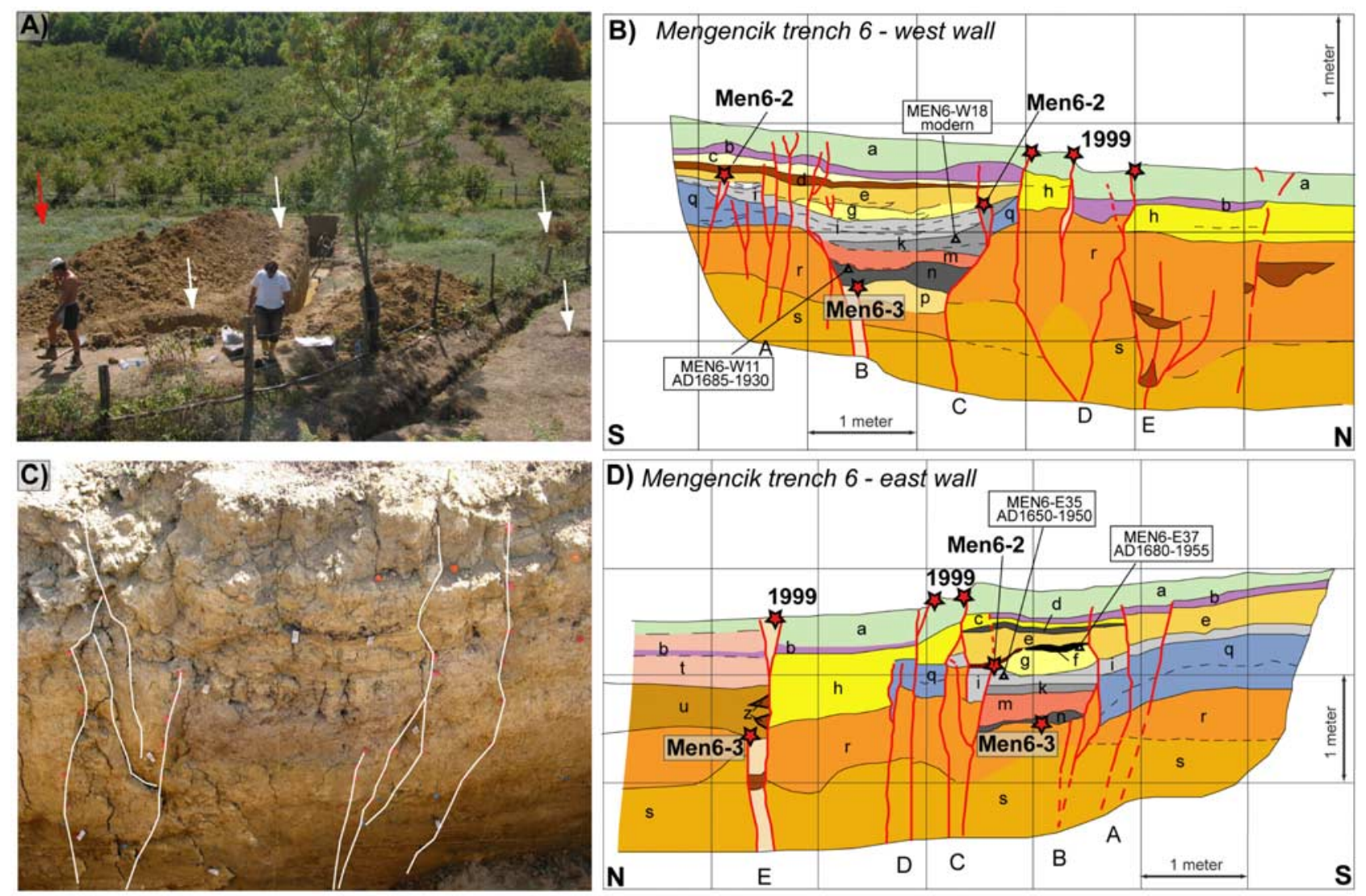

Figure 4. (a) View from north of the Men6 trench (location in Figure 3), arrows point to the main 1999 surface ruptures. (b) Simplified log of the southern fault zone west wall. (c) view of the southern fault zone east wall. (d) Simplified log of the southern fault zone east wall. Stratigraphy in Figures $4 \mathrm{~b}$ and $4 \mathrm{~d}$ : $\mathrm{a}$, active soil, generally ploughed up to $30 \mathrm{~cm}$ depth; b, organic silt; c, yellow silt; d, organic silt; e, massive yellow silt with small sandy and granular channels at the base; f, burn layer and reworked material from the burn layer near fault $\mathrm{C}$; g, yellow silt and fine sand with laminations of white clay and sand, locally convoluted; $h$, yellowish silt, it is possibly equivalent to units $b-g$ and include $q$; $i$, organic pale grey silty-sand, layered; $\mathrm{k}$, organic grey silty-sand with sparse pebbles and small charcoal; $\mathrm{m}$, red silt, with granules, intense weathering; $n$, grey silt, locally more clay rich; $p$, dark yellow silt, drier than the lower one; q, orange (weathered) silt with a whitish package at the base; r, massive yellow silt and silty sand (probably derived from the compaction of different layers) including also roots and organicrich beds; s, massive clayey silt to fine sand; same origin as $r$; $t$, blocky silt, light brown with a orange layer in the middle possibly correlated with $b$; $u$, dark yellow silt with weathered iron nodules; $z$, fine gravel in a silty-sandy matrix, gutter channels. Stars indicate event horizons, and black triangles are sample locations (dating details in Table 1).

[12] Evidence for an older event, Kay4, was found at fault zones 2 and 3. On the western wall, the northern strand of fault zone 2 offset only g and older units. Similar features define Kay4 also in fault zone 3.

[13] On the basis of the dated samples (Table 1), the timing of the above paleoearthquakes can be constrained as follows: Kay2 is younger than A.D. 1475, Kay3 occurred between A.D. 1035 and 1640, and Kay4 between A.D. 685 and 1220 .

\subsection{Mengencik Trench Site}

[14] A total of six trenches were excavated at Mengencik trench site (MEN) (Figure 4) across the 1999 ruptures (about $3.7 \mathrm{~m}$ dextral and $0.4 \mathrm{~m}$ vertical according to Akyüz et al. [2000, 2002] and Pucci et al. [2007a]). Five of the trenches were located in the western part of the site and one in the eastern. In the following, we present results only from the three fault-perpendicular trenches (Men1, Men5, and Men6, Figure 3b).

\subsubsection{Eastern Trench: Men6}

[15] Trench Men6 was opened about $200 \mathrm{~m}$ east of the western trenches (Men1 and Men5) where the 1999 earthquake surface ruptures formed a 12-m-wide graben hosting an ephemeral drainage (Figure 3). The coseismic graben structure coincides with a larger morphological depression, which indicates that the same pattern of surface ruptures has repeated in the past at this location.

[16] The sediments exposed in the trench walls form a monotonous alluvial fan aggradation sequence of silt, fine sand and clay with rare gravel intercalations (see Figure 4 


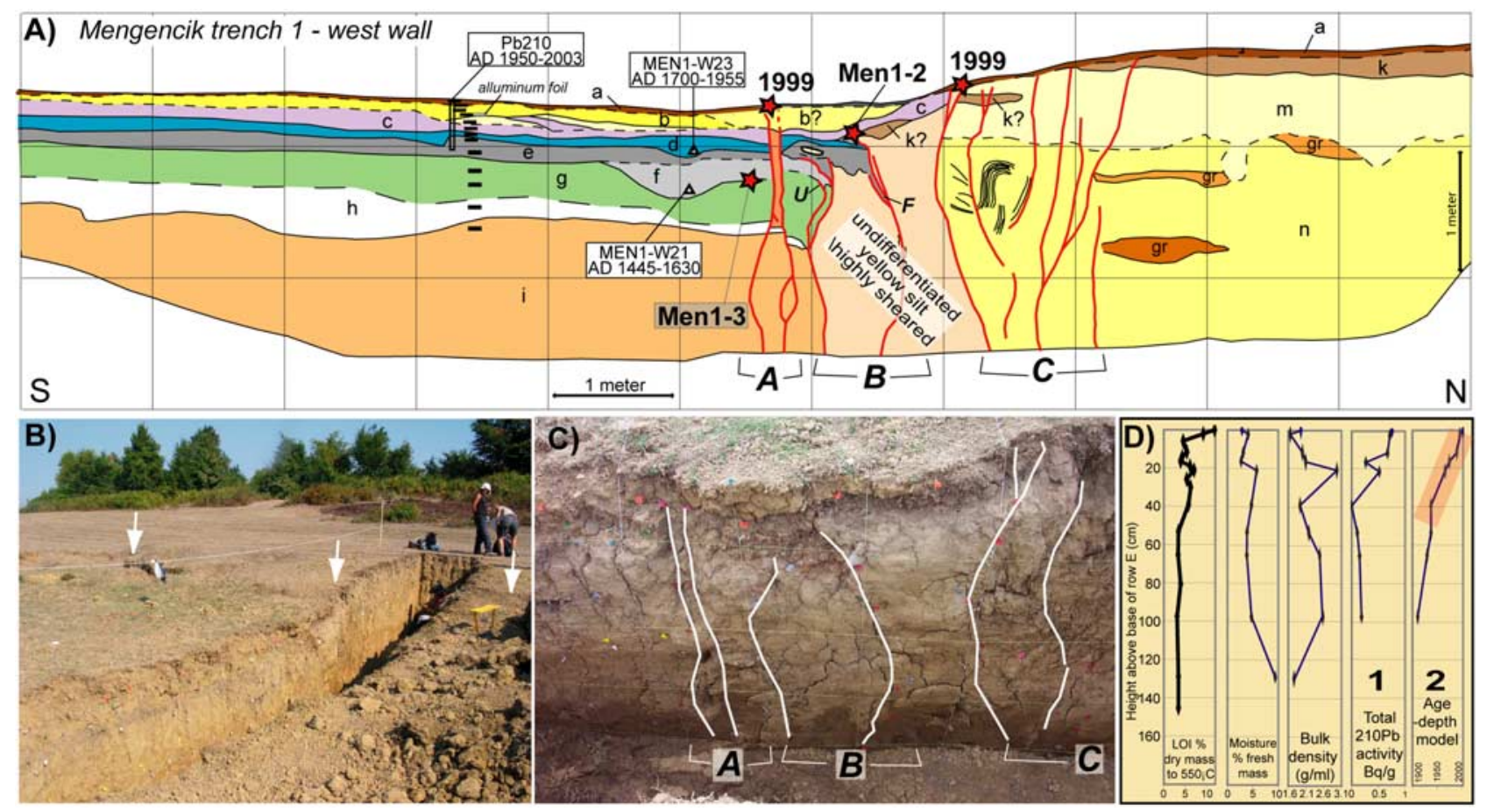

Figure 5. (a) Simplified log of the main fault zones of the Men1 trench (location in Figure 3). Stars indicate event horizons, black triangles are radiocarbon dated samples (details in Table 1), black rectangles are locations of samples for ${ }^{210} \mathrm{~Pb}$ analysis, open vertical rectangle encloses the deposits whose expected ${ }^{210} \mathrm{~Pb}$ age is indicated in the rectangle above. Stratigraphy: a, root mat; $b$, yellow silt and fine sand intercalated to root mat layers; c, grey silt, organic with small concretions; d, yellow silt and clay with small nodules and sparse pebbles up to $1 \mathrm{~cm}$, sand pockets at places; e, grey silt, organic with small concretions (paleosoil?); f, grey silt, with a charcoal-rich layer at the bottom (fire?); g, yellow silt and clay, with mottles and concretions up to $3-4 \mathrm{~cm}$; h, sparse white marls fragments (mean size $1-2 \mathrm{~cm}$ ) in brown-yellow silt; i, massive yellow-brown silt and clay, orange mottles, 1-2 cm iron nodules, few sparse large clasts from the marls, pieces of ceramics; k, brownish silt, blocky, organic, paleosoil locally interbedded with yellow silt; m, pale yellow silt, blocky and dry; n, massive yellow-brown silt, with iron nodules and locally gravel channels (gr) more clay rich at the bottom. (b) View of trench from south, arrows show the 1999 surface ruptures. (c) View of the main zone of faulting, west wall. (d) Summary of results for ${ }^{210} \mathrm{~Pb}$ dating.

for description of stratigraphic units). The organic component becomes important in the southern part of the trench, probably related to localized formation of a small marsh. The fault zone bounding the graben to the north was composed of several, subparallel, south dipping splays that reach the surface or the plow zone. Here, the stratigraphy was very homogeneous and contained too many ambiguities to be of use for individual paleoearthquake recognition. Conversely, the southern fault zone is more complex and is composed of several splays, some of which bound the main graben (E and D) and others (B and C), forming a small secondary graben (Figure 4).

[17] In order to provide a chronology of the exposed sediments, we collected several charcoal samples for ${ }^{14} \mathrm{C}$ analyses. Four of these samples were dated (see Table 1 and Figure 4). Three of them have overlapping ages younger than circa A.D. 1650 (samples MAN6-W11, MAN6-E35, MAN6-E37). Conversely, the forth, sampled from unit q yields a modern age (sample MAN6-W18). As a whole, we can conclude that the deposits filling the small secondary graben of the southern fault zone (units above $n$ ) are younger than A.D. 1685 (Figure 4).

[18] The 1999 earthquake ruptures produced slip mainly on faults $\mathrm{E}, \mathrm{D}$ and $\mathrm{C}$ of the southern fault zone with a clear down-to-the-north vertical component, indicated by free faces still visible at the surface. Paleoearthquake evidence is derived from stratigraphic and structural relations at the southern fault zone, where we found evidence for at least two paleoearthquakes predating 1999 (Figure 4). Evidence of the penultimate event Men6-2 is clear on both trench walls. On the $\mathrm{W}$ wall (Figure $4 \mathrm{~b}$ ) it is defined by a small graben between faults $\mathrm{A}$ and $\mathrm{C}$, with faults sealed by the yellow silt of unit e filling it. On the E wall (Figure 4d) the event horizon is defined on the basis of (1) faulting of a burn layer (unit f), successive backward erosion of the free face and filling of a depression by unit e; (2) upward fault terminations at the top of unit $\mathrm{i}$; and (3) possible paleoliquefactions within layer $g$. Thus the event horizon for Men6-2 is set at the base of unit e. Recognition of an additional event (Men6-3) is based on upward terminations of fault $\mathrm{B}$ capped by unit $\mathrm{n}$ on both walls and of fault zone $\mathrm{E}$ 


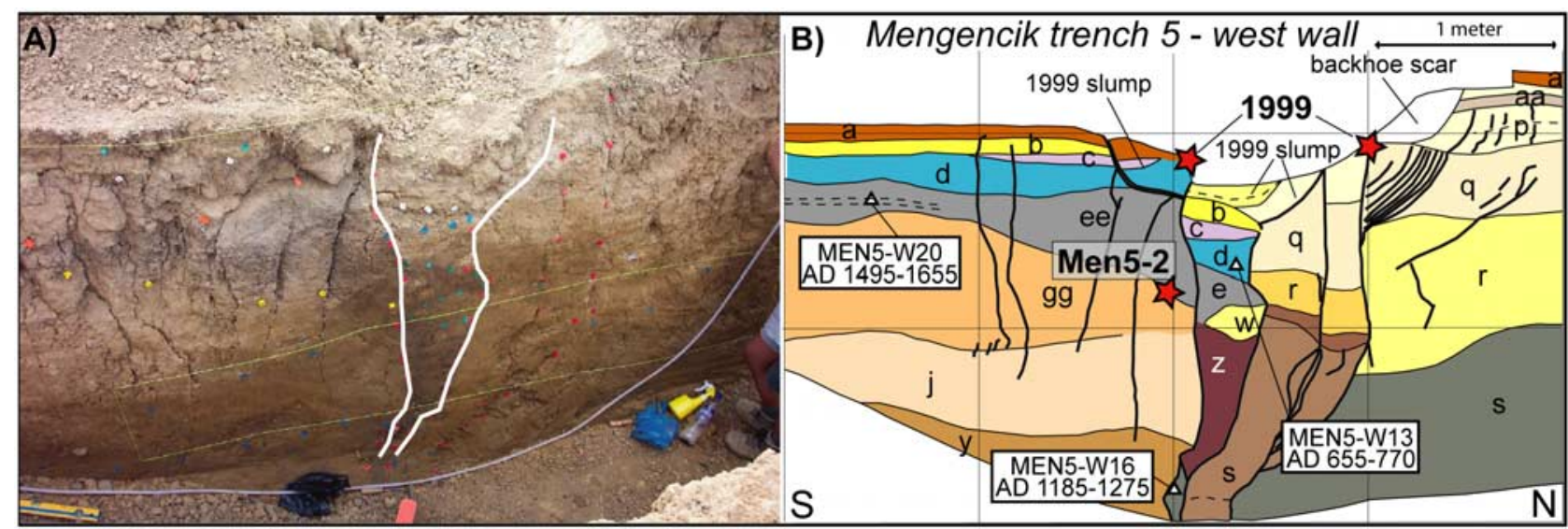

Figure 6. (a) View of the west wall of trench Men5 (location in Figure 3). Notice the main fault zone that here appears as a negative flower structure. (b) Simplified log of the main fault zone of the Men5 trench west wall. Stars indicate event horizons, and black triangles are sample locations (details in Table 1). Stratigraphy: a, root mat; b, yellow silt and fine sand frequently containing root mat layers; $c$, organic grey silt, with small concretions; d, yellow silt and clay with small nodules and sparse pebbles up to $1 \mathrm{~cm}$, sand pockets at places; ee, organic grey silt, with small concretions, with a charcoal-rich layer at the bottom (fire?), possibly deposited in a scarp-controlled pond; gg, white silt with sparse fragments of marls up to $3 \mathrm{~cm}$ size; j, yellow silty clay, with local concentration of fine granular gravel; y, yellowbrown clay mottled and with oxidized small clasts; w, mottled brown organic clay; $\mathrm{z}$, brown-reddish organic clay and silt; aa, organic brownish silt, blocky, locally interlayered with yellow silt; $p$, blocky yellow silt; q, sheared yellow-grey silt with rare nodules; r, highly compact pale yellow silt with sparse clasts of marls and ceramics; s, yellowish silty clay particularly sheared in the fault zone.

under unit $\mathrm{u}$ on the east wall. Also, the fact that unit $\mathrm{n}$ is organic-rich, in striking contrast to the surrounding units ( $\mathrm{r}$ and s), may suggest that it was deposited in a faultcontrolled depression with marsh vegetation.

[19] With the presently available radiocarbon ages (Table 1), we can only conclude that event MAN6-2 occurred within the past $\sim 300$ years, whereas MAN6-3 occurred close to or before A.D. 1685 (because it triggered the formation of the pond containing the dated samples). The presence of a modern sample from the units predating the penultimate earthquake remains a problem; excluding it was wrongly sampled from a young carbonized root, we have to admit that sample pollution occurred, in the field or in the lab.

\subsubsection{Western Trenches: Men1 and Men5}

[20] The 1999 earthquake surface fault at the western part of the Mengencik site crosses slope wash deposits and small coalesced fans composed mainly of silt. Overall, the fault trace produces relative subsidence of the southern side, where ponding is observed against the scarp, especially where the rupture forms small grabens. Repetition of surface faulting events produced the formation of faultparallel ridges of various sizes, which clearly control the drainage pattern (Figure 3).

[21] Trench Men1 was excavated across the 1999 rupture zone (Figures $5 \mathrm{a}$ and $5 \mathrm{~b}$ ) where it exhibits an apparent reverse component. The trench exposed a massive fan aggradation sequence of silt, fine sand and clay with rare gravel intercalations, derived from the marly deposits forming the range located to the south of the site (see Figure 5 for description of stratigraphic units). Some layers were rich in organic matter, possibly due to periods of surface stability (soil formation) or ponding events related to pre-1999 surface ruptures (judging from the fact that ponding occurred at this site after the 1999 earthquake). Trench Men5 was excavated about $25 \mathrm{~m}$ east of trench Men1 (Figure 3), where the 1999 ruptures formed a 1- to 2-m-wide graben. Similar to Men1, this trench exposed a massive fan aggradation sequence (Figure 6). Most of the stratigraphy can be directly correlated to that of trench Men1 and, in fact, the same labeling was used for layers which are inferred to correlate. In both trenches the fault zone was about $2 \mathrm{~m}$ wide and consisted of several splays in an arrangement that reflects the type of structure observed at the surface: positive flower structure at Men1 and negative at Men5 (Figures 5 and 6). Most of the splays reached the surface, indicating that they ruptured also during the 1999 earthquake. Only fault splay B in Men 1 (Figures 5a and 5c) did not rupture in 1999 and thus it provides good evidence for a previous surface faulting event.

[22] To provide a timeframe to the trenched sediments, we collected samples for ${ }^{14} \mathrm{C}$, and ${ }^{210} \mathrm{~Pb}$ analyses. Radiocarbon dating was quite difficult because of the extremely small size of the available samples. The dated samples (see Table 1 and Figures 5 and 6) suggest that the upper $60-70 \mathrm{~cm}$ of sediments, in the southern part of both trenches, was deposited in the past $\sim 500$ years (samples Men1-W21 and Men5-W20), with the upper $40 \mathrm{~cm}$ being younger than A.D. 1700. Sample Men5-W16 from the bottom of the sediments that were trapped in the shear zone indicates that these are $\sim 800$ years old. One additional sample dated from unit $\mathrm{d}$ of trench Men5 (Men5-W13) yielded an age indicating presence of reworked material in this environment. 

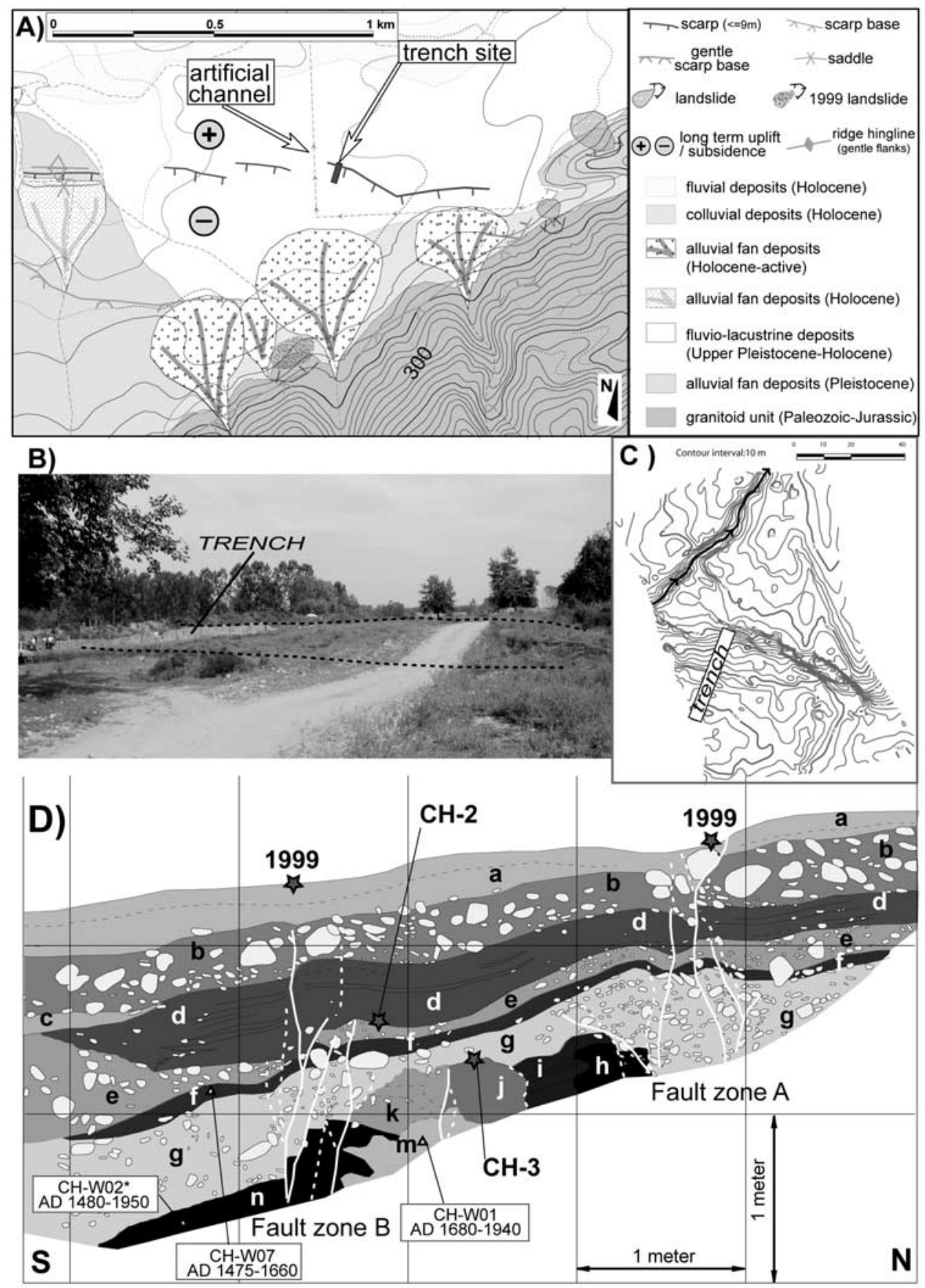

Figure 7. (a) Geomorphological map of the Caki Haci Ibrahim trench area. Contours are every $10 \mathrm{~m}$ from 1:25,000 topographic maps. (b) View of the 1999 scarp looking north, dashed lines underline top and base of the scarp, trench in the left background. (c) Microtopographic map of the trenched scarp from a 860 point total station survey. Notice the small left-stepping scarps; rectangle outlines the trench, blue, dark line is an ephemeral drainage. (d) Simplified log of the main fault zone. Stars indicate event horizons, black triangles are sample locations (details in Table 1); the star next to the sample name indicates that the sample was located outside this panel and its position is thus based on stratigraphic correlation. Stratigraphy: a, coarse sand fining upward to sandy silt or silt, locally fine pebbles at the bottom; organic soil developed on the upper part; $b$, very coarse pebbles, cobbles and small boulders in a fine pebbles and coarse sand matrix; $d$, coarse sands interfingering with pebbles (up to coarse); e, medium to coarse pebbles, small and large cobbles in a fine pebbles and coarse sand matrix; f, silty sand and very fine pebbles, includes sparse very coarse pebbles; g, very coarse pebbles, cobbles and small boulders in granular loose matrix; h, silt and sand; i, alternating beds of coarse sands, fine pebbles and silt; j. silt and silty sand; k, silt, sand, fine pebbles and sparse coarse pebble; $\mathrm{m}$, grey clay including large pieces of wood, with coarse sand and fine pebbles on top; $\mathrm{n}$, silt including layers of sand and fine pebbles. 
[23] ${ }^{210} \mathrm{~Pb}$ analysis was completed on the sequence to assess the validity of the radiocarbon chronology and to better constrain the age of the younger part of the stratigraphy in trench Men1. Sampling was performed in the southern part of the trench, from the surface to the bottom of the trench (Figure 5a); analyses were performed for the upper $1.24 \mathrm{~m}$. The ${ }^{210} \mathrm{~Pb}$ activity shows a general decline with depth (column 1 in Figure $5 \mathrm{~d}$ ). The ${ }^{210} \mathrm{~Pb}$ activity is noticeably higher in the top $40 \mathrm{~cm}$ of the sediment sequence than lower in the sequence. By using the constant rate supply model [Appleby, 2001], we generate ${ }^{210} \mathrm{~Pb}$ age estimates for the upper $40 \mathrm{~cm}$. and produce a reference chronology (column 2 in Figure 5d) which suggests that the upper $40 \mathrm{~cm}$ accumulated since the mid-20th century. The stratigraphic unit at $40 \mathrm{~cm}$ depth (unit e in Figure 5), which exhibits very low ${ }^{210} \mathrm{~Pb}$ activity, is characterized by a blocky pedogenic structure and is interpreted as a probable paleosoil. The ${ }^{210} \mathrm{~Pb}$ activity increases below the paleosoil, probably reflecting in situ ${ }^{210} \mathrm{~Pb}$ production. A single ${ }^{14} \mathrm{C}$ date of A.D. 1450-1630 (sample Men1-W21) from below the paleosoil unit e supports the hypothesis that this soil represented a phase of relative surface stability and pedogenesis between the 17th-19th centuries. After the paleosoil formation a new phase of sediment deposition took place. In agreement with this, a ${ }^{14} \mathrm{C}$ date from immediately above the paleosoil yields a young age, possibly younger than A.D. 1880 (60\% probability, sample Men1-W23). A small piece of aluminum foil, found within unit $b$, is also supportive of the youthfulness of these upper units.

[24] At the site of trench Men1 the 1999 earthquake formed a gentle south facing scarp, with the ruptures clearly reaching the surface at fault zones A and C. Evidence for at least 2 paleoearthquakes predating 1999 was found on the basis of stratigraphic and structural relations at both trenches (Figures 5a and 6b).

[25] The penultimate earthquake, Men1-2, was associated with intense deformation at fault zone $\mathrm{B}$, where the grey organic silt units $\mathrm{e}, \mathrm{f}$ and $\mathrm{d}$ (and $\mathrm{k}$ ?) were taken into the fault zone, sheared, and buried by the yellow silt and clay and the organic grey silt layers of units b and c. A third event, Men1-3, can be inferred on the basis of the upper termination of the southern branch of fault zone B (U in Figure 5a) below unit $f$ coupled to the presence and geometry of the grey organic silt units $\mathrm{f}$ and $\mathrm{e}$, which can be interpreted as postearthquake ponding deposits that accumulated inside a depression in front of a coseismic scarp, similar to the one formed by the 1999 earthquake. At trench Men5 the 1999 earthquake rupture produced a graben-like structure at the surface (negative flower structure), with the free faces still clearly visible in 2004 (Figure 6). The determination of the penultimate event, Men5-2, is based only on the assumption that similar to what was observed after the 1999 earthquake, surface faulting earthquakes at this location produce faultcontrolled ponding. On this basis and because of the peculiar thickening of the comparatively organic-rich unit ee toward the fault zone, we assume that this unit deposited in a depression created by surface faulting; thus it buried (postdates) an event horizon (Men5-2). Older events produced intense shearing and slicing of the sediments, accompanied by deposition of organic-rich silt and sand within fault-controlled ponds in the fault zone.
[26] On the basis of the available dating (Table 1), we can conclude that the penultimate earthquake at the western trenches of Mengencik site (Men1 and Men5) is recognized only in Men1 and postdates the deposition of unit d: thus it occurred after the development of the pedogenic layer e. According to radiocarbon dating (Men1-W23) this event is younger than A.D. 1700 , with a $\sim 60 \%$ probability of being younger than 1880 that although with uncertainties, is in agreement with ${ }^{210} \mathrm{~Pb}$ modeling suggesting that this event occurred in recent times, possibly close to 1900. Paleoearthquake Men1-3 has a perfect stratigraphic and age correspondence with Men5-2 and is expected to have occurred in the past $\sim 500$ years.

\subsection{Cakir Haci Ibrahim Trench}

[27] The Cakir Haci Ibrahim $(\mathrm{CH})$ trench was excavated in the floodplain of the Develi River, across a gentle and broad cumulative south facing scarp (Figures $1 b$ and 7). In this area, the 1999 ruptures formed a $100 \mathrm{~m}$ wide left step over locally composed of smaller-scale left-stepping scarplets (Figure 7). At this site the 1999 earthquake dextral and vertical offsets were about 3.8 and $1.0 \mathrm{~m}$, respectively [Akyüz et al., 2000, 2002; Pucci et al., 2007a]. Because of their geometry and kinematics, the 1999 ruptures completely dammed an artificial channel probably built along a natural drainage flowing northward from the range toward the Develi River (Figures $1 \mathrm{~b}$ and $7 \mathrm{a}$ ).

[28] The trench exposed 5 fault zones, distributed within a 20-m-wide zone, displacing gravel-dominated alluvial plain deposits, including layers of sand and silt (see Figure $7 \mathrm{~d}$ for description of stratigraphic units in the main fault zone). The main faults of this zone, A and B, are associated with the main flexural scarp, whereas the others with minor scarps (not included in the log of Figure 7d).

[29] In order to provide chronological constraints for the trench deposits, charcoal and wood samples were collected and three of them dated (Table 1). Although in a stratigraphically older or equivalent position, sample $\mathrm{CH}-\mathrm{W} 01$ yielded ages younger (A.D. 1680-1940) than CH-W02 and CH-W07 (A.D. 1488-1950 and A.D. 1475-1660, respectively). This discrepancy may be due to inclusion of older charcoal in the sequence for sample $\mathrm{CH}-\mathrm{W} 07$, which is a small fragment of detrital charcoal, or to pollution of one of the wooden samples CHW-02 and CH-W01. Because this issue cannot be solved with the present data we can conclude that the exposed sequence is younger than 500, possibly 300 years.

[30] The 1999 earthquake is recorded on various strands of the main and secondary fault zones, which either reach the surface, or deform the uppermost stratigraphic unit a, with or without discrete vertical displacements. A small scarplet with a free face, superimposed on the broader flexure, is still visible at fault zone A (Figure 7d).

[31] Evidence for one and possibly two paleoearthquakes predating 1999 was also found. On the basis of the intense deformation of units $\mathrm{h}$ to $\mathrm{n}$ and of fault strands that terminate in, or below unit g, a distinct event horizon $\mathrm{CH}-3$ is defined at the top of unit $\mathrm{j}$, or within g. Subtle upward fault terminations at the base or within the lower part of unit $\mathrm{d}$ are suggestive of a further paleoearthquake $\mathrm{CH}-2$. This is supported also by the smaller deformation of unit $d$, with respect to e, f and $\mathrm{g}$. 

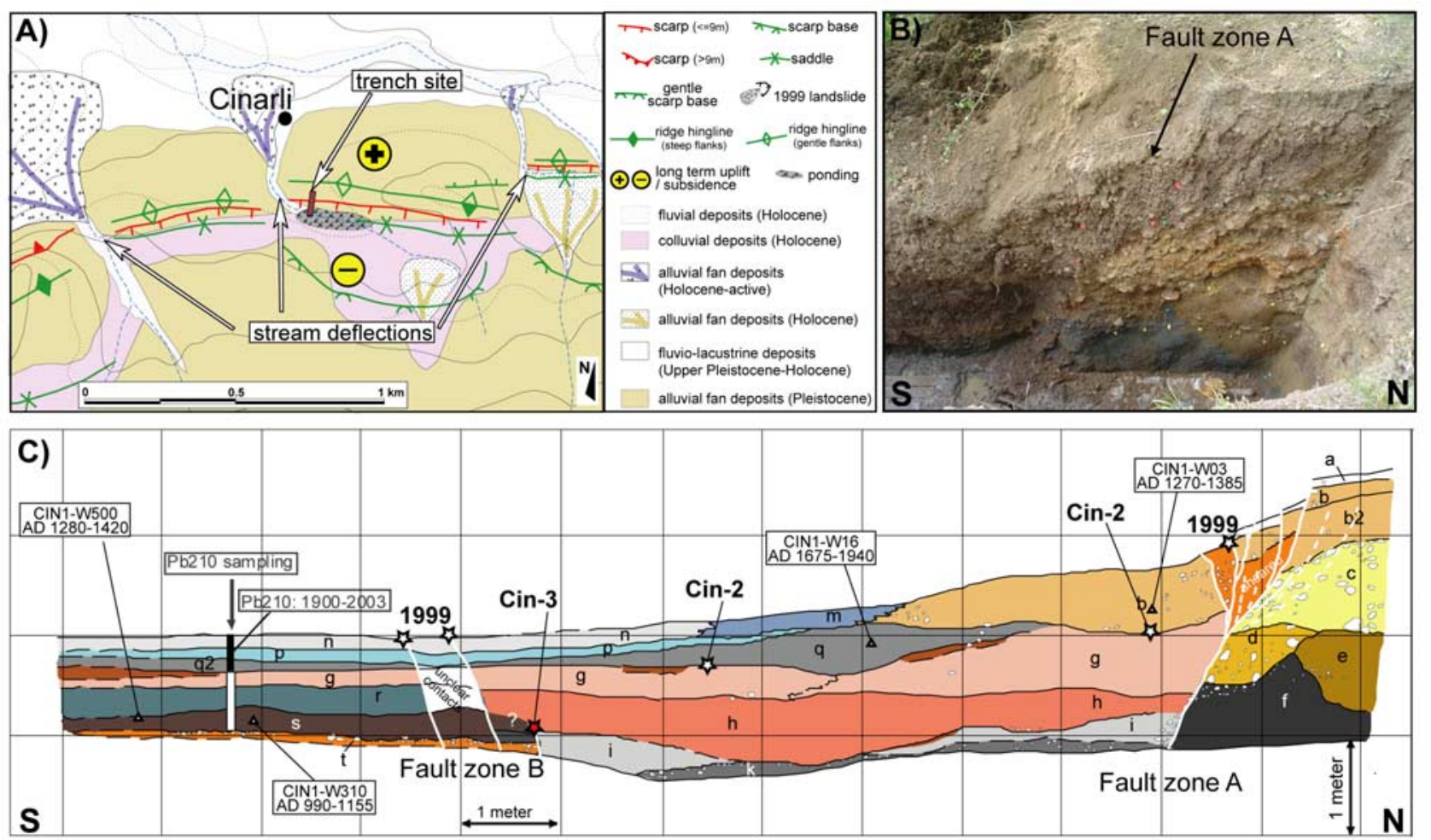

Figure 8. (a) Geomorphological map of the Cinarli trench area (location in Figure 1b). (b) View of the normal fault zone A (see Figure 8c) (c) Simplified log of the west wall. Stars indicate event horizons; black triangles are sample locations (details in Table 1); vertical rectangle shows the sequence sampled for ${ }^{210} \mathrm{~Pb}$, the solid upper portion is the part for which the age-depth model of Figure $9 \mathrm{c}$ is considered reliable. Stratigraphy: a, active soil; $b$, colluvium, silty fine sand with sparse round pebbles, finer southward, interpreted as scarp-derived deposit postdating the pre-1999 event; b2, silty fine sand with few rounded pebbles; c. gravel in pale orange silty sand matrix, with big $(6-8 \mathrm{~cm})$ rounded pebbles; $\mathrm{d}$, channel deposits, with big rounded pebbles in a orange-brown matrix; e, channel deposits, with few small rounded pebbles in a brownish matrix; f, same as e but with a grey-blue clay matrix due to local reduction processes, clearly sheared in the fault zone; g, weathered brown-orange silt, with small pebbles and locally clayey patches; it turns into a brownish silty clay in the central part of the trench and into a grey-brown clay southward; at the top a distinct paleosoil $10-20 \mathrm{~cm}$ thick, h, pale brown clayey silt, locally with a red weathered horizon $(10 \mathrm{~cm}$ thick) at its top; $i$, grey-blue silty clay with coarse sand to fine gravel at its bottom, it turns into a grey clay southward, some red weathering locally identified at its top; $\mathrm{k}$. fine to medium size gravel in grey silty-clay matrix; $\mathrm{m}$, brownish silty clay with small pebbles, it represent the distal part of unit $\mathrm{b}$ (colluvium) and it interfingers with unit $\mathrm{n}$ southward; $\mathrm{n}$, brownish clay, with several small roots from the grass above, the development of a soil horizon is probably not permitted by frequent overflooding of the nearby channel; $p$, dark black-brown clay, it becomes dark grey northward; q/q2, dark brown to dark grayish purple clay with a small amount of silt increasing northward, it turns into a grey-brown clay to the south; r, dark grey clay, with patches of whitish clay at the bottom; s, black sandy silt, coarser at the bottom, with wood and plants concentrated in the upper part, ends abruptly northward; t, brown gravel, coarser to the south, ends abruptly northward.

[32] Given the controversial age results and the uncertain evidence of $\mathrm{CH}-2$, we can only conclude that at least two paleoearthquakes are recognized in this trench and took place during the past 500 , possibly 300 , years.

\subsection{Cinarli Trench}

[33] The Cinarli trench (CIN) is located in an area were repeated activity along the Düzce fault is testified by a series of tectonic ridges that have developed on Pleistocene and Holocene deposits of a bajada formed in front of the Almacik range front (Figures $1 \mathrm{~b}$ and $8 \mathrm{a}$ ). These ridges strongly control the drainage pattern and alluvial fan deposition, causing damming of streams and development of marsh areas. The trench was opened across a compound scarp along which one of the 1999 fault traces occurred with about $1 \mathrm{~m}$ vertical and $0.5 \mathrm{~m}$ dextral movements, producing the damming of a creek flowing toward the Düzce plain. A second rupture occurred a few meters to the south, almost parallel to the first but with only a horizontal slip component ( 3 m) [Akyüz et al., 2000, 2002; Pucci et al., 2006]. The deposits exposed in the trench walls can be subdivided into two groups (see caption of Figure 8 for stratigraphy): 

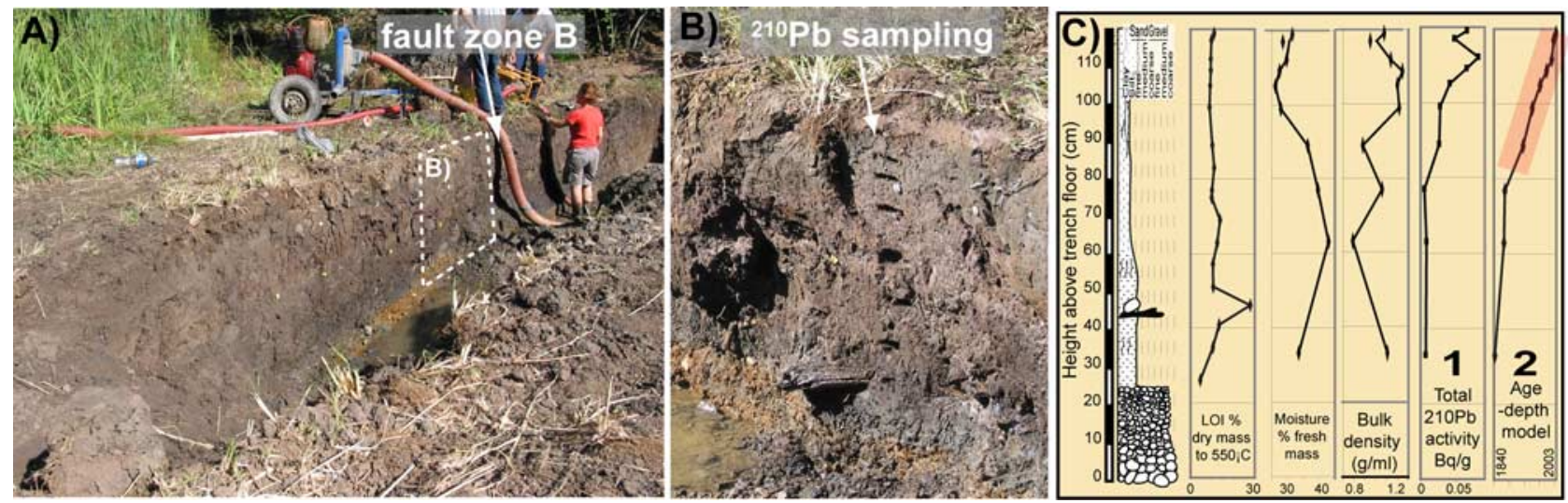

Figure 9. (a) View of the Cinarli trench from the south, notice the low energy organic deposits ponding against the main scarp offset by the fault zone B (see Figure 8c); rectangle encloses the location of the ${ }^{210} \mathrm{~Pb}$ sampling. (b) Detail of the ${ }^{210} \mathrm{~Pb}$ sampling location. (c) Summary of results for ${ }^{210} \mathrm{~Pb}$ dating.

those close to the compound normal scarp to the north, which are mainly fluvial channel and scarp-derived sediments, and those related to the stream floodplain to the south (q2, r, s, t) that are mainly silt, clay, and fine sand with important organic content. Deposition was clearly episodic and rootlet beds suggest some hiatuses. Two fault zones deform the entire sequence and coincide with the ruptures produced by the 1999 earthquake (Figures 8b, 8c, and 9). Fault zone A is very clear, shows an important vertical component and consists of a main trace splaying into several strands at about $1.5 \mathrm{~m}$ below the surface. The geometry of fault zone B was not documented in detail because instability caused continuous collapse of the walls at its location.

[34] To provide a timeframe for the exposed sediments, we collected samples for ${ }^{14} \mathrm{C}$ and ${ }^{210} \mathrm{~Pb}$ analyses (Table 1 and Figure 8c). Reworking of wood and charcoal fragments can explain the incongruous ages obtained from layer $\mathrm{s}$ (samples CIN1-W500 and CIN1-W310) and the stratigraphic inversion between CIN1-W16 and CIN1-W03. Because of this, in the following interpretation we use only the younger ages. Layers $\mathrm{g}, \mathrm{h}, \mathrm{b}$ and $\mathrm{n}$ to $\mathrm{s}$ were all deposited during the past $\sim 700$ years (A.D. 1280, sample CIN1-W500), unit $q$ and those above it are younger than A.D. 1675, whereas sample CIN1-W03, likely derived from the erosion of the scarp, can be used to infer that the top layers of the gravel sequence north of the main fault zone are deposited circa A.D. 1270 or after.

[35] ${ }^{210} \mathrm{~Pb}$ analysis was used to better constrain the age of the younger part of the stratigraphy. Sampling was performed in the southern part of the trench, from the surface to the top of the gravel unit $\mathrm{t}$ (Figure 9). The ${ }^{210} \mathrm{~Pb}$ activity shows a broadly exponential decline with depth. The ${ }^{210} \mathrm{~Pb}-$ derived chronology extends from the surface to around $40 \mathrm{~cm}$ depth (i.e., units $\mathrm{n}, \mathrm{p}$ and $\mathrm{q} 2$ in Figure 8). Below this depth the modeled chronology is not considered reliable because the activity levels were at a background level, probably reflecting in situ ${ }^{210} \mathrm{~Pb}$ production. The mean accumulation rate over the last century has been approximately $0.4 \mathrm{~cm} / \mathrm{a}$ since unit q2), with an increase in accumulation rates in the late $1990 \mathrm{~s}(\sim 0.6 \mathrm{~cm} / \mathrm{a})$. Although these "average" figures should be treated with caution as depo- sition likely occurred in pulses, these can provide good boundary values for the age of the sequence if no substantial changes of depositional environment occur.

[36] The 1999 rupture was still clearly visible along the main fault zone. The portion of the rupture occurring close to the bottom of the compound scarp showed four closely spaced splays that produced a clear vertical offset of the surface, with the southern side down. Conversely, evidence for 1999 surface faulting was less clear at fault zone B, where important shearing up to the uppermost clay units is suggested by the absence of clear contacts in the deformation zone and instability of the trench wall. The 1999 coseismic deformation caused damming of the stream and consequent flooding of the area. This is also verified by the decline in ${ }^{210} \mathrm{~Pb}$ activity identified at $2 \mathrm{~cm}$ depth (layer $\mathrm{n}$ ), probably reflecting the input of old material derived erosion of the newly formed fault scarp and intensification of human activities to clear the area.

[37] Evidence for two paleoearthquakes predating the 1999 is found in this trench as well (Figure 8c). The penultimate event (CIN-2) is recognized on the basis of the presence of a wedge-shaped unit of scarp-derived colluvium (unit b), interfingering with recent marsh deposits to the south (unit $m$ ). The colluvium rests on top of a unit of grey clay (unit q) and a brown-orange silt close to the scarp (unit g). The presence of a paleosoil at the top of unit $g$ suggests that the event horizon of CIN-2 is at the top of $\mathrm{g}$ and coincides with the abrupt change in depositional environment passing from a stable ground surface to fresh water inundation similar to the change following the 1999 earthquake. The possibility that CIN-2 occurred at the top of unit q cannot be excluded though. Evidence for a third earthquake back in time (CIN-3) is found at fault zone B. Faulting during this event juxtaposed the yellow-brown gravel (unit t) and black sandy silt (unit s) against the grey clay (unit i). Coseismic damming of the local stream resulted in deposition of drift wood (top of unit s) and a change from an intermittent infill of an abandoned channel to a low-energy overbank and back-swamp depositional environment (unit $r$ and above).

[38] By merging results from both ${ }^{14} \mathrm{C}$ and ${ }^{210} \mathrm{~Pb}$ analyses, we tried to constrain the timing of paleoearthquakes. 

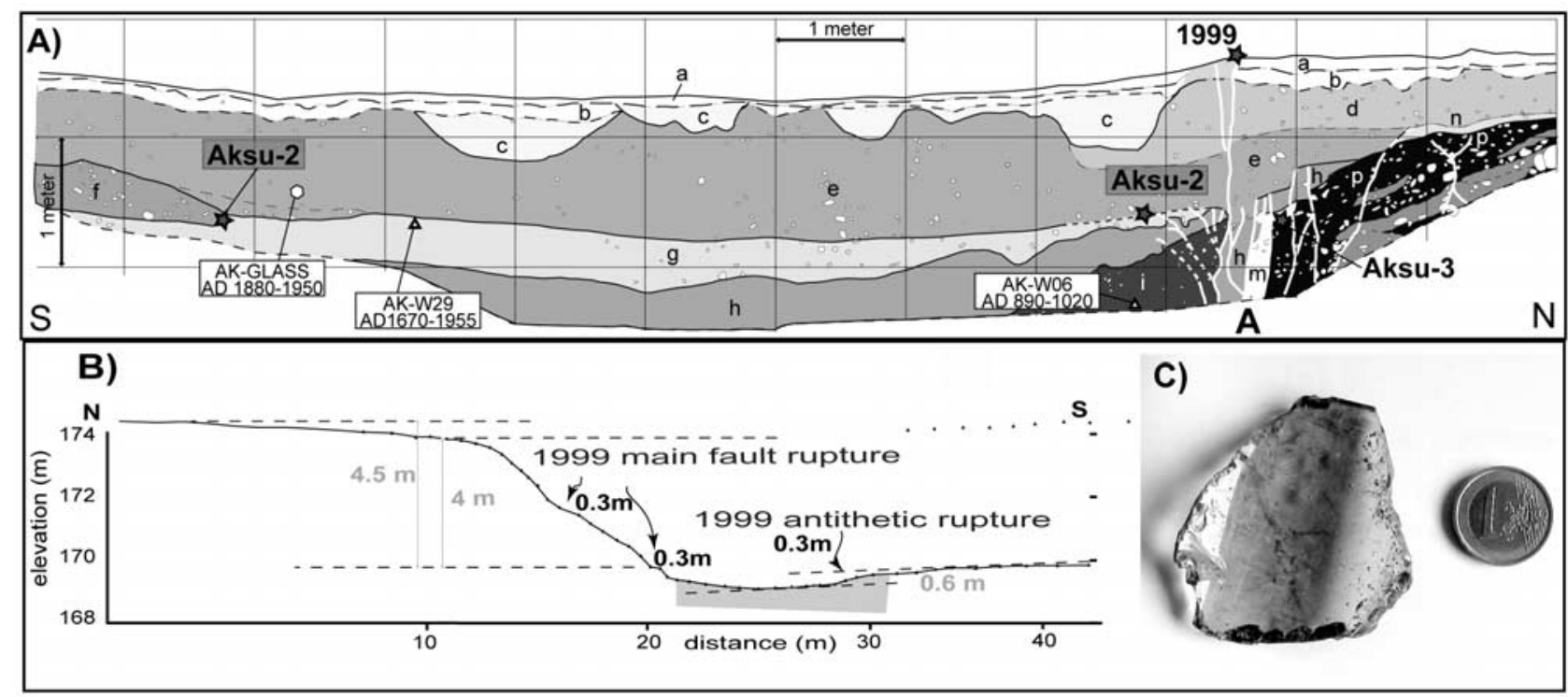

Figure 10. (a) Simplified log of the west wall of the Aksu trench. Stars indicate event horizons, triangles are radiocarbon sample locations (details in Table 1); hexagon shows the location of the glass fragment. Stratigraphy: a, silty light brown active soil with roots; b, dark silt with pebbles at the bottom (base of ploughed zone); c, U-shaped crumbly brownish silt with pebbles (root zones of big dead trees) only in the southern part of the trench; d, light brown mud with sparse pebbles; e. brown silt with sparse pebbles; f, pebbles, cobbles and small granules in a clayey silty matrix, wedge-shaped deposit interfingering with unit e (scarp-derived colluvium); g, brown silty clay with rare pebbles; $h$, yellowish brown silt with rare pebbles, more clayey in the upper part; i, dark brown silt with pebbles (up to $4 \mathrm{~cm}$ in diameter); $\mathrm{m}$, brownish silt with pebbles (only in the fault zone); $n$. yellow silt only on top of unit $p, 10$ to $20 \mathrm{~cm}$ thick, top eroded toward the fault zone; $\mathrm{p}$, alluvial fan: sandy silt with cobbles and pebbles, locally lens of fine gravel, coarse sand and boulders (light color). (b) Topographic profile across the main and antithetic scarps. The 1999 earthquake throws and cumulated scarp heights are shown (black and gray, respectively). Gray box is the projection on the profile of the trench that was open about $5 \mathrm{~m}$ east of the profile trace. (c) Glass fragment found in the lower part of unit e (hexagon in Figure 10a).

Radiocarbon dating shows that unit q, which probably postdates event CIN-2, is younger than A.D. 1675 (CIN1W16). Because this age derives from detrital charcoal, it provides a maximum age for the hosting sediments. Therefore, regardless of whether the event horizon is at the base or top of unit q (see above), we assume the age of sample CIN1-W16 to be a maximum age for CIN-2. By correlating layers on both sides of fault zone $\mathrm{B},{ }^{210} \mathrm{~Pb}$ suggests that unit q2 and those above it were deposited during the past $\sim 100$ years. If this is correct, the penultimate event CIN-2 occurred near the end of the 19th century.

[39] According to sample CIN1-W500 that was collected at the top of the sediments faulted by event CIN-3, this event is younger than A.D. 1280. If we use the rates of sedimentation extrapolated from ${ }^{210} \mathrm{~Pb}$ for the upper $40 \mathrm{~cm}$ to the CIN-3 event horizon, event CIN-3 may be as young as A.D. 1700. However, given the intermittent type of sedimentation characterizing the site, this latter age estimate without further constraints appears too speculative.

\subsection{Aksu Trench}

[40] The Aksu (AK) site is located near the western termination of the November 1999 earthquake rupture (Figure 1b). In this area the 1999 surface rupture zone generally runs at the base of the range front and has a predominantly vertical sense of displacement. Measured coseismic offsets were about 0.3 dextral and $0.7-1.7 \mathrm{~m}$ vertical [Akyüz et al., 2000, 2002; Pucci et al., 2007a]. At the trench site the 1999 rupture strikes about E-W, cutting through a major alluvial fan and the deposits of a younger fan developed on it. The rupture is composed of a primary north facing scarp and an antithetic fault that is nearly parallel to it, with both showing evidence of cumulative slip (Figure 10). For logistic reasons the trench was dug across the antithetic scarp.

[41] The trench was excavated in a NNE-SSW direction and (Figure 10) and exposed a sequence of massive units that can be subdivided into three groups. The uppermost (units $\mathrm{a}-\mathrm{c}$ ) are soil horizons. The second group includes all the slope wash and colluvial deposits (units $\mathrm{d}$ to $\mathrm{m}$ ). The third group includes the alluvial fan layers (units $\mathrm{n}$ and $\mathrm{p}$ ). A description of all stratigraphic units is given in Figure 10. We found a single fault zone in the northern part of the trench, coincident with the 1999 antithetic scarp (Figure 10), which separates the alluvial fan from the colluvial-slope wash units. The fault zone is formed by several subvertical splays which become more numerous at the trench bottom.

[42] In order to constrain the age of the exposed sediments, we dated two charcoal samples. The radiocarbon age of a sample collected from the oldest of the colluvial/slope 
Table 2. Synthesis of Paleoearthquakes of the Düzce Fault $\mathrm{t}^{\mathrm{a}}$

\begin{tabular}{|c|c|c|c|}
\hline Surface Faulting Events & Earthquake Correlation & Age Interval & Confidence \\
\hline \multicolumn{4}{|l|}{$\begin{array}{l}\text { Trench KAY, 40.776095, } 31.313858 \\
\text { (WGS84) }\end{array}$} \\
\hline Most recent (KAY-1) & DUZ-1 & A.D. 1999 & $100 \%$ \\
\hline Penultimate (KAY-2) & DUZ-2 & after A.D. 1475 & high \\
\hline Event KAY-3 & DUZ-3 & A.D. $1035-1640$ & medium \\
\hline Event KAY-4 & DUZ-4 & A.D. $685-1220$ & high \\
\hline \multicolumn{4}{|l|}{$\begin{array}{l}\text { Trench MEN6, 40.774718, } 31.248849 \\
\text { (WGS84) }\end{array}$} \\
\hline Most recent (MEN6-1) & DUZ-1 & A.D. 1999 & $100 \%$ \\
\hline Penultimate (MEN6-2) & DUZ-2 & A.D. $1685-1900$ & high \\
\hline Event MEN6-3 & DUZ-3 & $\begin{array}{l}\text { close to or before } \\
\text { A.D. } 1685-1900\end{array}$ & high \\
\hline \multicolumn{4}{|l|}{$\begin{array}{l}\text { Trench MEN5, 40.7746660, } 31.246047 \\
\text { (WGS84) }\end{array}$} \\
\hline Most recent (MEN5-1) & DUZ-1 & A.D. 1999 & $100 \%$ \\
\hline Penultimate (MEN5-2) & DUZ-3 & A.D. $1495-1900$ & medium \\
\hline \multicolumn{4}{|l|}{$\begin{array}{l}\text { Trench MEN1, 40.774660, } 31.246047 \\
\text { (WGS84) }\end{array}$} \\
\hline Most recent (MEN1-1) & DUZ-1 & A.D. 1999 & $100 \%$ \\
\hline Penultimate (MEN1-2) & DUZ-2 & $\begin{array}{l}\text { A.D. } 1700-1900 \\
\text { (possibly close to A.D. } \\
1880-1900^{b} \text { ) }\end{array}$ & medium-high \\
\hline Event MEN1-3 & DUZ-3 & A.D. $1445-1900$ & medium \\
\hline \multicolumn{4}{|l|}{$\begin{array}{l}\text { Trench CH, 40.766222, } 31.131424 \\
\text { (WGS84) }\end{array}$} \\
\hline Most recent $(\mathrm{CH}-1)$ & DUZ-1 & A.D. 1999 & $100 \%$ \\
\hline Penultimate (CH-2) & DUZ-2 & A.D. $1488(1680)-1900$ & low \\
\hline Event $\mathrm{CH}-3$ & DUZ-3 & A.D. $1488(1680)-1900$ & medium-high \\
\hline \multicolumn{4}{|l|}{$\begin{array}{l}\text { Trench CIN, 40.765541, } 31.111827 \\
\text { (WGS84) }\end{array}$} \\
\hline Most recent (CIN-1) & DUZ-1 & A.D. 1999 & $100 \%$ \\
\hline Penultimate (CIN-2) & DUZ-2 & $\begin{array}{l}\text { A.D. } 1675-1900 \\
\text { (possibly close to } \\
\text { A.D. } 1900^{\text {b }} \text { ) }\end{array}$ & high \\
\hline Event CIN-3 & DUZ-3 & $\begin{array}{l}\text { A.D. } 1280-1700 \\
\text { (possibly close to } \\
\text { A.D. } 1700^{\text {b }} \text { ) }\end{array}$ & medium-high \\
\hline \multicolumn{4}{|l|}{$\begin{array}{l}\text { Trench Aksu 40.7569, } 30.9562 \\
\text { (WGS84) }\end{array}$} \\
\hline Most recent (Aksu-1) & DUZ-1 & A.D. 1999 & $100 \%$ \\
\hline Penultimate (Aksu-2) & DUZ-2 & $\begin{array}{l}\text { after A.D. } 1670-1900 \text { and } \\
\text { before A.D. } 1880-1900^{c}\end{array}$ & high \\
\hline Event Aksu-3 & DUZ-4 & $\begin{array}{l}\text { A.D. } 685-1020 \\
\text { possibly A.D. } 890-1020\end{array}$ & low-medium \\
\hline
\end{tabular}

${ }^{a}$ The surface faulting events are those recognized at each trench; the earthquake correlation is that of paleoearthquakes at different locations along the fault naming them DUZ1 to DUZ4, where DUZ1 is the 1999 earthquake; the $2 \sigma$ dendrocorrected age interval of occurrence of the event is given based both on radiocarbon, ${ }^{210} \mathrm{~Pb}$ dating, or archaeological evaluations, the confidence interval is the one that we attributed an arbitrary confidence level based on the constraints existing on the recognition and dating of the event itself.

${ }^{\mathrm{b}} \mathrm{The}{ }^{210} \mathrm{~Pb}$ dating.

${ }^{\mathrm{c}}$ Archaeological evaluations.

wash units (sample AK-W06) indicates that the postalluvial fan deposits are younger than A.D. 890. Sample AK-W29, collected at the top of unit $\mathrm{g}$, indicates that the upper meter of sediments is younger than 300 years.

[43] A broken piece of glass found $\sim 80 \mathrm{~cm}$ below the surface within unit e (Figures 10a and 10c) is clearly transported material, and thus it provides a maximum age for the enclosing deposit. On the basis of its thickness, weight, color, type of fracture, inclusions, wall regularity, etc, an age of A.D. 1880-1950 is suggested (A. Delfino, personal communication, 2006).

[44] The 1999 antithetic earthquake ruptures still appears at this site as a 30 -cm-high free face. The same amount of offset can be measured at least at the base of soil $b$
(Figure 10a). On the basis of stratigraphic and structural relations, and taking into consideration the fact that this trench was excavated across a secondary antithetic splay of the 1999 main ruptures, which may not necessarily record all the surface faulting earthquakes that have occurred at this location, we found evidence for a minimum of two paleoearthquakes predating 1999 (Figure 10a). The penultimate event (Aksu-2) is well defined by the distinct upward termination of several fault splays and important downward increase of deformation at the top of unit $g$. Unit $f$ at the southern end of the trench is a wedge-shaped deposit, formed by coarse gravel different from that of the units above and below it. This unit is interpreted as the northern tip of a scarp-derived colluvium related to the postevent 
erosion of the main scarp immediately south of the trench. This strengthens the location of an event horizon at the contact between e and g.
[45] At least one previous paleoevent (Aksu-3) is responsible for the intense shearing of the alluvial fan deposits (unit p, completely missing in the hanging wall of the antithetic fault zone), and of the subsequent deposition of

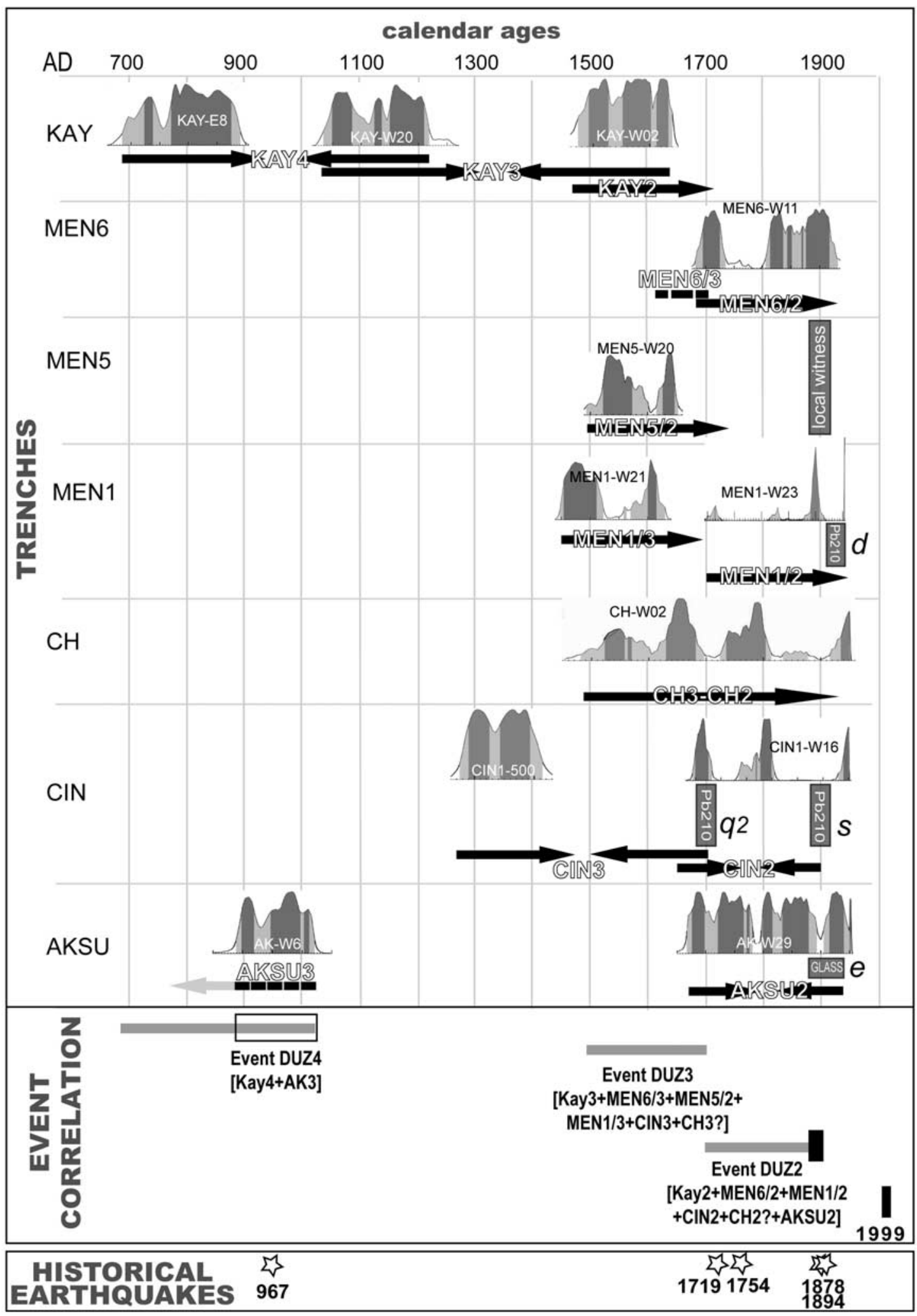

Figure 11 
the colluvial unit $\mathrm{i}$. This latter unit is likely to have been deposited in a coseismic depression formed between the main and antithetic faults. The event horizon of Aksu-3 can be tentatively placed at the top of the alluvial fan deposits (unit $\mathrm{p}$ ).

[46] With the available ages, we can constrain the age of the penultimate earthquake (Aksu-2) sometimes after the deposition of unit $\mathrm{g}$ and before the age of the glass, that is, after A.D. 1670 (AK-W29) and before A.D. 1880-1950 (AK-GLASS). If unit $\mathrm{i}$ represents a postevent deposit following the occurrence of Aksu-3 and the age of sample AK-W06 is not substantially older than the hosting unit, this paleoearthquake should have occurred before or close in time to A.D. 890-1020. In fact, the dated sample is a small piece of charcoal enclosed in a scarp-derived deposit and probably come from the erosion of the top of the scarp; thus it may represent the age of the ground surface at the time of the event and not necessarily the age of the colluvium postdating the event.

\section{Paleoearthquakes of the Düzce Fault}

[47] On the basis of sedimentary and structural relations, we found evidence for 2 to 3 surface faulting paleoearthquakes predating the 1999 event in all the trenches.

[48] Radiocarbon dating was rather problematic due to sample characteristics and their young ages, resulting in possible age ranges of occurrence of paleoearthquakes that are quite broad. In fact, as already mentioned, because most of the dates recovered from the trenched deposits fall within the radiocarbon plateau (see section 2), thereby preventing the determination of a precise age due to the fact that measured radiocarbon ages in the plateau calibrate with almost equal probability to any age within it, we decided not to invest in more radiocarbon dating but to integrate them with ${ }^{210} \mathrm{~Pb}$ analyses and archaeological information. On the other hand, according to historical documentation and instrumental seismicity compilations (given that the 1900s represent the beginning of the seismic instrumentation era), we can affirm that no large earthquakes occurred on the Düzce fault since then. Thus we trim all the paleoearthquakes max age to A.D. 1900 (Table 2).

[49] Under the assumption that similar to the 1999 event, paleoearthquakes on the Düzce fault ruptured the whole fault, we correlate events between different trenches on the basis of their age compatibility and the local sequence of the events. This assumption is considered likely because, as discussed in the initial part of this paper, the $40-\mathrm{km}$-long Düzce fault appears to be controlled by two persistent boundaries: the junction to the Karadere fault to the west, and the Bakacak-Elmalik releasing step over to the east. Merging the radiocarbon results obtained from all the trenches, it is possible to propose a seismic history for the Düzce fault for the past 1000-1200 years.

[50] Table 2 and Figure 11 summarize the age ranges of the paleoearthquakes recognized in each trench and their possible correlation. We named the correlated paleoearthquakes of the Düzce fault prior to 1999 event as DUZ2, DUZ3 etc. Evidence for each of them is derived from different trenches. As already stated, evidence for the 1999 surface ruptures are clear in all the trenches. On the contrary, evidence for the other Düzce events is not always found in every trench. As a first approach, in absence of clear stratigraphic constraints we assume that the same sequence of events is repeated in each trench, however, if no age compatibility exist we attempt a different correlation.

[51] Merging radiocarbon ages from different trenches to constrain the age of DUZ2 yields the occurrence of this event sometime in the past 300 years. Thus DUZ2 occurred between A.D. 1700 and 1900 . The ${ }^{210} \mathrm{~Pb}$ analysis from Cinarli trench (Figures 8 and 9) and the age estimate of the piece of glass from Aksu trench (Figures 10a and 10c) suggest that DUZ2 occurred close to A.D. 1900. Interestingly, local people living near trench MEN6, at Fendikli village, reported to us a family story about cracks at the same location of the 1999 ones, produced by an earthquake at the end of the 19th century. Unfortunately, no independent evidence for this has been found yet.

[52] On the basis of radiocarbon dating, the occurrence of DUZ3 is confined during the past 500 years. The youngest age for DUZ3 can be set to A.D. 1640 from trench KAY, and to circa A.D. 1700 from CIN and MEN6. Because the KAY and MEN6 constraints derive from charcoal dating that represents the maximum age for the hosting sediments, we take in consideration the wider range derived from ${ }^{210} \mathrm{~Pb}$ analysis in CIN trench. Controversial evidence from radiocarbon dating of $\mathrm{CH}$ trench and rates of sedimentation from ${ }^{210} \mathrm{~Pb}$ from CIN trench would set the occurrence of DUZ3 to

\footnotetext{
Figure 11. Correlation of paleoearthquakes along the Düzce fault and inferred age ranges. (top) Report on the radiocarbon age probability distribution (dark grey $1 \sigma$, light grey $2 \sigma$ ), as well as the ${ }^{210} \mathrm{~Pb}$ and the archaeological estimates (rectangles, lowercase letters indicate the stratigraphic unit for which the ${ }^{210} \mathrm{~Pb}$ refer to), used to set the age of an event horizon in each trench. Black arrows indicate whether the sample predates or postdates the event. Dashed gray lines indicate a preferred age for the event given the stratigraphic considerations discussed in the text. Names of the events are indicated and are the same used in the logs (Figures 4-10) and in Table 2. (middle) Correlations among trenches. In most cases events are correlated between trenches on the basis of their age compatibility and on the local sequence of the events. The event horizons from each trench that concurred to the recognition of the correlated events are reported in brackets. Grey horizontal lines represent the best age range for the event on the basis of radiocarbon dating and assuming, on a historical/instrumental basis, that the penultimate earthquake occurred before A.D. 1900. Black rectangles (with exception for the 1999 earthquake that is known) show preferred ages of events obtained by including also the other types of dating. Open rectangle for DUZ4 is indicative of the preferred part of the range obtained on the basis of stratigraphic considerations. Correlated events are renamed as DUZ2 to DUZ4; these represent pre-1999 surface faulting earthquakes that ruptured the same fault extent as in 1999 (see discussion in text). (bottom) Historical earthquakes (stars) known to have occurred in proximity of the Düzce fault.
} 


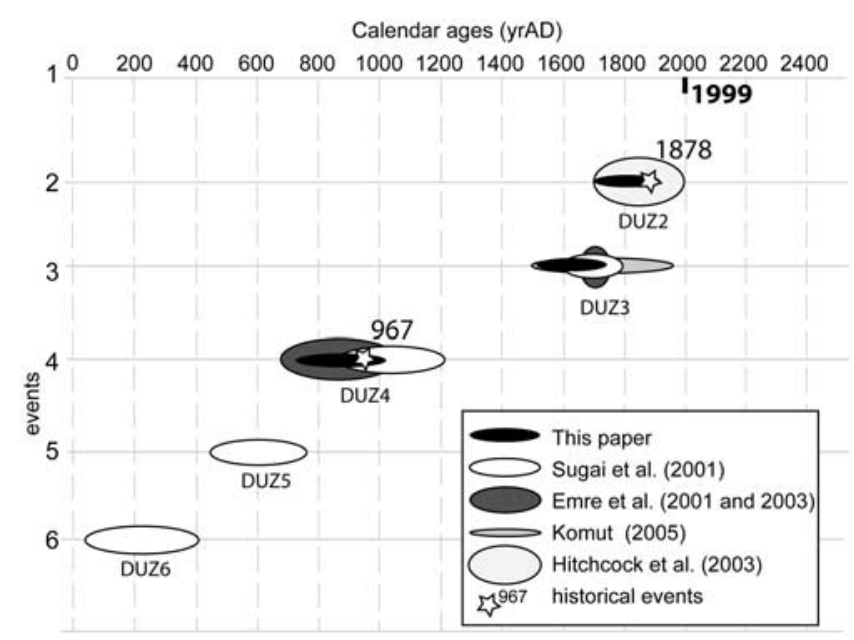

Figure 12. Integration of paleoseismological results from this work and previous ones. Ellipses show the age range uncertainties for paleoearthquakes, and tones of grey indicate different papers. Correlated historical earthquakes are shown too (stars). One of the events recognized in this work, occurred during the past 500 years (DUZ2 or DUZ3) was not recognized before. Recent earthquakes appear to have occurred more closely spaced than previous ones.

circa A.D. 1700. With the present data this cannot be confirmed and future investigations should resolve this issue.

[53] Limited evidence and age constraints exist for DUZ4 that falls in the interval A.D. 685-1020. On the basis of stratigraphic considerations from Aksu trench the age of occurrence of DUZ4 can be possibly limited to the range A.D. $890-1020$.

\section{Discussion}

\subsection{Comparison of Paleoearthquakes With the Historical Record}

[54] On the basis of paleoseismological investigation we found evidence for three surface faulting paleoearthquakes that ruptured the Düzce fault before the November 1999 event. The two most recent ones occurred during the past 500 years, with the penultimate (DUZ2) possibly around A.D. 1900, and the third event back (DUZ3) between A.D. 1500 and A.D. 1700. The oldest event (DUZ4) occurred between A.D. 685 and A.D. 1020 and possibly in the period A.D. 890-1020 (Figure 11). There are no obvious correlations of the paleoearthquakes with the large events reported in the historical catalogues [Ambraseys and Finkel, 1995; Guidoboni et al., 1994; Guidoboni and Comastri, 2005]. In fact, as already mentioned, even though historical information for damaging earthquakes exists in Turkey for the past 2000 years, we found no clear information connecting specific earthquakes to the Düzce fault. This is probably a consequence of the limited settlement of the Düzce area that even nowadays is mainly an agricultural center. The only historical earthquakes that are known to have produced damage near the Düzce fault are the (1) A.D. 967 that was felt in the area of Bolu, (2) A.D. 1719 earthquake that appears to be a perfect twin of the August 1999 Izmit earthquake, (3) A.D. 1754 that is located in the Sapanca area, (4) A.D. 1878 earthquake that is hypothesized on the
Hendek fault or in the Akyazi plain, and (5) A.D. 1894, which occurred on the Izmit fault segment farther west [Ambraseys and Finkel, 1995; Ambraseys, 2002, 2006; Atakan et al., 2002; King et al., 2001] (see Figure 1 for earthquake mezoseismal areas).

[55] It is interesting to note that according to our paleoseismological results (Figure 11), the A.D. 1719, A.D. 1878, A.D. 1894 and A.D. 967 earthquakes are all compatible with a rupture of the Düzce fault. However, given the historical damage reports, only the A.D. 1878 and A.D. 967 earthquakes appear to be good candidates for DUZ2 and DUZ4. Even though tempting (see the $\mathrm{CH}$ trench paleoearthquakes dating discussion), it would be difficult to extend the 1719 rupture as far as the Düzce fault to correlate it to DUZ3. Given the low density of population and lack of cultural centers in the area, records of DUZ3 (A.D. 15001700) may have been lost or overprinted by the disaster produced by the 1719 earthquake farther west.

\subsection{Comparison With Results of Previous Paleoseismological Studies on the Düzce Fault}

[56] Previous paleoseismological investigations [Sugai et al., 2001; Emre et al., 2001, 2003a, 2003b; Hitchcock et al., 2003; Komut, 2005] show evidence for surface faulting paleoearthquakes during the past 2000 years or more. In general, because of the location and type of depositional environment at trench sites, these works present a seismic history that is longer but with less control on the young events than that presented in this work. Figure 12 summarizes results from all previous works on the Düzce fault, together with those from this work. In order to make the data set homogeneous, we dendrochronologically corrected ages for some of the published events, excluded events with limited or unclear age constraints, and included only the events of the past two millennia.

[57] In this work we have clear and independent stratigraphic evidence for the occurrence of three events, including 1999, during the past 500 years (1999, DUZ2, DUZ3). On the contrary, the previous works show evidence for only one event predating 1999 during the same time interval. Whether it is DUZ2 or DUZ3 that correlates to the penultimate earthquake from previous works cannot be constrained with the present data. The previous event (DUZ4) may correlate with an event at circa A.D. 1000 found by Sugai et al. [2001] and Emre et al. [2001, 2003a, 2003b]. We find no evidence from our trenches for two older events at circa A.D. 600 and circa A.D. 200 that were described by Sugai et al. [2001] (Figure 12).

\subsection{Implications for Earthquake Recurrence}

[58] On the basis of the results from this work, four events since A.D. 685-1020 (possibly A.D. 890-1020) yield an average recurrence for the Düzce fault of 330 430 years (possibly $330-370$ years). If we include paleoearthquakes from previous studies, which reach farther back in time 2000 years, we obtain a similar figure for the average recurrence of 320-390 years. However, the three most recent events, including 1999, appear more closely spaced. Average recurrence for the four older events (DUZ3 to DUZ6) can range between 360 and 560 years, whereas for the three most recent (1999 to DUZ3) can range between 140 and 250 years. 
[59] We have to note that less frequent earthquakes as we move back in time may merely be the result of a lack of complete sedimentary sequences for paleoseismological interpretation. Should we consider the paleoseismic record to be complete, the sequence depicted in Figure 12 would be suggestive of a slight acceleration and earthquake clustering in time [Wallace, 1987].

[60] It is interesting to note that similar results are also derived from paleoseismological trenching in the Mudurnu valley (southern splay of the NAFZ west of Bolu, see introduction, across the 1967 earthquake ruptures [Palyvos et al., 2007; Ikeda et al., 1991]. There, at least two paleoearthquakes preceding the 1967 event were recognized during the past $\sim 600$ years, with the penultimate possibly younger than A.D. 1700 or correlating with one of the 1668 events of the NAFZ. Although with the present data it is not possible to evaluate the coupling in time of events rupturing the Düzce and Mudurnu sections, these results suggest a similarity in seismic moment release.

[61] A 200- to 300-year average recurrence is obtained through paleoseismological works along other neighboring North Anatolian fault sections, namely, the Izmit section to the west and the Gerede section to the east [Okumura et al., 2002; Klinger et al., 2003; Rockwell and Meghraoui, 2003; Ferry et al., 2004]. The longer recurrence intervals of the Düzce and Mudurnu sections may be the result of strain accumulation that, along this part of the NAFZ, is partitioned between the Mudurnu and the Düzce parallel faults strands.

\subsection{Insights on the Slip Rate of the Düzce Fault}

[62] As already mentioned, no measurements of coseismic offset from trenches were possible. If we assume that the Düzce fault is a segment of the NAFZ defined by persistent segment boundaries (see section 1) and that the 1999 coseismic slip is representative for the behavior of this fault, we may use the average recurrence time from our study coupled with the $2.7 \mathrm{~m}$ average and $5 \mathrm{~m}$ maximum surface coseismic slip, to obtain a first approximation figure of fault slip rate. If we take the most conservative average recurrence time, calculated including all the six events that have occurred during the past $\sim 2$ millennia (i.e., $320-$ 390 years), the $2.7 \mathrm{~m}$ average and $5 \mathrm{~m}$ maximum surface coseismic slip yield a slip rate of $\sim 6.9-8.4$ and $12.8-$ $15.6 \mathrm{~mm} / \mathrm{a}$, respectively. The short-term slip rate derived from the 1999 maximum slip compares well with that of $11.8-18.2 \mathrm{~mm} / \mathrm{a}$ obtained for the past $60 \mathrm{ka}$ from cumulative offset geomorphic markers [Pucci et al., 2007b], whereas that derived from the 1999 minimum slip appears substantially smaller. The $\approx 10 \mathrm{~mm} / \mathrm{a}$ slip rate derived from GPS measurements [Ayhan et al., 1999, 2001] falls in between the two extremes inferred from paleoseismological recurrence. All of this suggests that the Düzce fault substantially accommodates, along with the Mudurnu section to the south, the $\sim 2 \mathrm{~cm} / \mathrm{a}$ of motion along the NAFZ in this area.

\section{Conclusions}

[63] Trenching along the Düzce fault has provided new data about the earthquake history of this part of the NAFZ, as well as new insights on earthquake recurrence.

[64] Although with uncertainties in dating, we recognized the geological evidence of three surface faulting earth- quakes prior to 1999. These are dated on the basis of radiocarbon, ${ }^{210} \mathrm{~Pb}$, and archaeological information and can be summarized as follows: DUZ2, A.D. 1685-1900, possibly end of 19th century; DUZ3, A.D. 1495-1700; and DUZ4, A.D. $685-1020$, possibly A.D. $890-1020$.

[65] None of the earthquakes reported in the historical seismic catalogues is known to have ruptured the Düzce fault. However, according to damage reports, the 1878 and 967 are good candidates for DUZ2 and DUZ4, respectively. The DUZ3 age range is close to 1719 and the hypothesis to correlate them is quite tempting. However, this contrasts with some historical observations and would need more supportive evidence. These paleoseismological results, merged with those from previous papers for the past two millennia, suggest an average recurrence of 320-390 years, with a possible increase of frequency during the past 500 years. Under the assumption that the Düzce fault generates 1999-type earthquakes with $2.7 \mathrm{~m}$ average and $5 \mathrm{~m}$ maximum offset at the surface, these recurrence intervals, allow for first approximation slip rate estimates for the past 2000 years of $6.9-8.4$ and $12.8-15.6 \mathrm{~mm} / \mathrm{a}$, respectively. These estimates are comparable to those from GPS [Ayhan et al., 1999, 2001] and cumulative offset of geomorphic markers [Pucci et al., 2007b].

[66] Acknowledgments. This work was supported by EU project RELIEF (EVG1-CT-2002-00069) and benefited of the field support and throughout discussion of M. Meghraoui, S. Akyüz, G. Uçarçus, A. Dikbas, D. Satir, and G. Sunal. We also wish to thank local authorities and land owners for letting us excavate trenches. We are indebted to Tom Rockwell, Isabelle Menighetti, and an anonymous reviewer for their reviews that substantially improved the paper.

\section{References}

Akyüz, H. S., A. A. Barka, E. Altunel, R. D. Hartleb, and G. Sunal (2000), Field observations and slip distribution of the November 12, 1999 Düzce earthquake $(M=7.1)$, Bolu-Turkey, in The 1999 Izmit and Düzce Earthquakes; Preliminary Results, edited by A. A. Barka et al., pp. 63-70, Istanbul Tech. Univ., Istanbul, Turkey.

Akyüz, H. S., R. D. Hartleb, A. A. Barka, E. Altunel, G. Sunal, B. Meyer, and R. Armijo (2002), Surface rupture and slip distribution of the 12 November 1999 Düzce earthquake $(M 7.1)$, North Anatolian Fault, Bolu, Turkey, Bull. Seismol. Soc. Am., 92(1), 61-66.

Altunel, E., A. A. Barka, Z. Çakır, Ö. Kozacı, C. Hitchcock, J. Helms, J. Bachhuber, and W. Lettis (2000), What goes on at the eastern termination of the November 12, 1999 Düzce earthquake, $M=7.2$, North Anatolian Fault, Turkey, Eos Trans. AGU, 81(48), Fall Meet. Suppl., F816.

Ambraseys, N. N. (2002), The seismic activity of the Marmara Sea region over the last 2000 years, Bull. Seismol. Soc. Am., 92(1), 1-18.

Ambraseys, N. N. (2006), Comparison of frequency of occurrence of earthquakes with slip rates from long-term seismicity data: The cases of Gulf of Corinth, Sea of Marmara and Dead Sea Fault Zone, Geophys. J. Int., $165,516-526$.

Ambraseys, N. N., and C. F. Finkel (1995), The Seismicity of Turkey and Adjacent Areas: A Historical Review, 1500-1800, 240 pp., Muhittin Salih Eren, Istanbul.

Appleby, P. G. (2001), Chronostratigraphic techniques in recent sediments, in Tracking environmental Changes Using Lake Sediments, vol. 1, Basin Analysis, Coring and Chronological Techniques, edited by W. M. Last and J. P. Smol, pp. 171-203, Kluwer, Dordrecht, Netherlands.

Armijo, R., B. Meyer, A. Hubert, and A. A. Barka (1999), Westward propagation of the North Anatolian fault into the northern Aegean: Timing and kinematics, Geology, 27(3), 267-270.

Atakan, K., A. Ojeda, M. Meghraoui, A. A. Barka, M. Erdik, and A. Bodare (2002), Seismic hazard in Istanbul following the 17 August 1999 Izmit and 12 November 1999 Düzce earthquakes, Bull. Seismol. Soc. Am., 92(1), 466-482.

Ayhan, M. A., C. Demir, A. Kiliçoglu, I. Sanli, and S. M. Nakiboglu (1999), Crustal motion around the western segment of the north Anatolian fault zone: Geodetic measurements and geophysical interpretation, paper presented at IUGG99, Int. Union of Geodesy and Geophys., Birmingham, U. K., 18-30 July. 
Ayhan, M. E., R. Burgmann, S. McClusky, O. Lenk, B. Aktug, E. Herece, and R. E. Reilinger (2001), Kinematics of the $M_{w}=7.2,12$ November 1999, Düzce, Turkey earthquake, Geophys. Res. Lett., 28(2), 367-370.

Barka, A. A., and K. Kadinski-Cade (1988), Strike-slip fault geometry in Turkey and its influence on earthquake activity, Tectonophysics, 7, 663684.

Barka, A. A., E. Altunel, S. Akyüz, Z. Cakır, Ö. Kozacı, W. Lettis, J. Bachhuber, C. Hitchcock, and J. Helms (2001), Seismic activity and fault segmentation of the NAF in the Bolu Mountain: Relationship between the November 12, 1999 and the February 1, 1944 earthquakes, paper presented at EUG XI Meeting, Eur. Union of Geosci., Strasbourg, France.

Bradley, R. S. (1985), Quaternary Paleoclimatology_Methods of Paleoclimatic Reconstruction, Unwin Hyman, London.

Christie-Blick, N., and K. T. Biddle (1985), Deformation and basin formation along strike-slip faults, in Strike-Slip Deformation, Basin Formation and Sedimentation, edited by K. T. Biddle and N. Christie-Blick, Spec. Publ. Soc. Econ. Paleontol. Mineral., 37, 1-34.

Cundy, A. B., and I. S. Stewart (2004), Dating recent colluvial sequences with ${ }^{210} \mathrm{~Pb}$ and ${ }^{137} \mathrm{Cs}$ along an active fault scarp, the Eliki Fault, Gulf of Corinth, Greece, Tectonophysics, 386, 147-156.

Cundy, A. B., P. E. F. Collins, S. D. Turner, I. W. Croudace, and D. Horne (1998), 100 years of environmental change in a coastal wetland, Augusta Bay, southeast Sicily: Evidence from geochemical and palaeoecological studies, in Sedimentary Processes in the Intertidal Zone, edited by K. S. Black, D. M. Paterson, and A. Cramp, Spec. Publ. Geol. Soc., 139, $243-$ 254

Emre, Ö., et al. (2001), Paleoseismologic findings on the Düzce Fault: North Anatolian Fault Zone, NW Turkey, Eos Trans. $A G U, 82(47)$, Fall Meet. Suppl., Abstract S52C-0651.

Emre, Ö., Y. Awata, and T. Duman (Eds.) (2003a), Surface Rupture Associated With the 17 August 1999 Izmit Earthquake, pp. 29-271, Gen. Dir. of Miner. Res. and Explor., Ankara, Turkey.

Emre, Ö., S. Toda, T. Y. Duman, T. Sugai, A. Dogan, Y. Awata, M. Okuno, H. Tsutsumi, S. Ozalp, and F. Tokay (2003b), Recurrence of the large earthquakes on the 1999 Izmit and Düzce surface ruptures, North Anatolian Fault, Turkey, Geophys. Res. Abstr., 5, 04635.

Ferry, M., M. Meghraoui, J.-F. Girard, T. K. Rockwell, O. Kozaci, S. Akyuz, and A. Barka (2004), Ground-penetrating radar investigations along the North Anatolian fault near Izmit, Turkey: Constraints on the right-lateral movement and slip history, Geology, 32(1), 85-88.

Guidoboni, E., and A. Comastri (2005), Catalogue of Earthquakes and Tsunamis in the Mediterranean Area From the 11th to the 15th Century, 1037 pp., Storia Geofis. Ambiente, Bologna, Italy.

Guidoboni, E., A. Comastri, and G. Traina (1994), Catalogue of Ancient Earthquakes in the Mediterranean Area Up to the 10th Century, 504 pp., Storia Geofisica Ambiente, Bologna, Italy.

Harris, R. A., and S. M. Day (1993), Dynamics of fault interaction: Parallel strike-slip faults, J. Geophys. Res., 98, 4461-4472.

Hitchcock, C., E. Altunel, A. A. Barka, J. Bachhber, W. Lettis, Ö. Kozci, J. Helms, and S. Lindvall (2003), Timing of late Holocene earthquakes on the eastern Düzce fault and implications for slip transfer between the southern and the northern strands of the North Anatolian Fault System, Bolu, Turkey, Turk. J. Earth Sci., 12(1), 119-136.

Ikeda, Y., Y. Suzuki, E. Herece, F. Saroglu, A. M. Isikara, and Y. Honkura (1991), Geological evidence for the last two faulting events on the North Anatolian fault zone in the Mudurnu Valley, western Turkey, Tectonophysics, 193(4), 335-345.

King, G., A. Hubert-Ferrari, S. S. Nalbant, B. Meyer, R. Armijo, and D. Bowman (2001), Coulomb interactions and the 17 August 1999 Izmit, Turkey earthquake, C. R. Acad. Sci., Ser. IIA, 333(9), 557-569.

Klinger, Y., K. Sieh, E. Altunel, A. Akoglu, A. Barka, T. Dawson, T. Gonzalez, A. Meltzner, and T. Rockwell (2003), Paleoseismic Evidence of Characteristic Slip on the Western Segment of the North Anatolian Fault, Turkey, Bull. Seismol. Soc. Am., 93(6), 2317-2332, doi:10.1785/ 0120010270

Komut, T. (2005), Paleoseismological studies on Düzce fault and geological data on the seismogenic sources in the vicinity of Düzce area, Ph.D. thesis,
155 pp., Kandilli Obs. and Earthquake Res. Inst., Boğaziçi Univ., Istanbul.

Okay, A. L., E. Demirbag, H. Kurt, N. Okay, and I. Kuscu (1999), An active, deep marine strike-slip basin along the North Anatolian Fault in Turkey, Tectonics, 18(1), 129-147.

Okumura, K., Y. Awata, T. Duman, F. Tokay, I. Kuscu, and H. Kondo (2002), Rupture history of the 1944 Bolu-Gerede segment of the North Anatolian Fault: Gerede-Ardicli Trench re-excavated, Eos Trans. AGU, 83(47), Fall Meet. Suppl., Abstract S11B-1155.

Palyvos, N., D. Pantosti, C. Zabci, and G. D'Addezio (2007), Paleoseismological evidence of recent earthquakes on the 1967 Mudurnu Valley earthquake segment of the North Anatolian Fault Zone, Bull. Seismol. Soc. Am., 97(5), 1646-1661, doi:10.1785/0120060049.

Pucci, S., N. Palyvos, C. Zabci, D. Pantosti, and M. Barchi (2006), Coseismic ruptures and tectonic landforms along the Düzce segment of the North Anatolian Fault Zone (Ms 7.1, November 1999), J. Geophys. Res., 111, B06312, doi:10.1029/2004JB003578.

Pucci, S., D. Pantosti, M. R. Barchi, and N. Palyvos (2007a), A complex seismogenic shear zone: The Düzce segment of North Anatolian Fault (Turkey), Earth Planet. Sci. Lett., 262, 185-203, doi:10.1016/ j.eps1.2007.07.038.

Pucci, S., P. M. De Martini, and D. Pantosti (2007b), Preliminary slip rate estimates for the Düzce segment of the North Anatolian Faul Zone from offset geomorphic markers, Geomorphology, doi:10.1016/ j.geomorph.2007.09.002, in press.

Reilinger, R. E., S. C. McClusky, M. B. Oral, R. W. King, M. N. Toksoz, A. A. Barka, I. Kinik, O. Lenk, and I. Sanli (1997), Global Positioning System measurements of present-day crustal movements in the ArabiaAfrica-Eurasia plate collision zone, J. Geophys. Res., 102(B5), 99839999.

Reilinger, R. E., M. N. Toksöz, S. C. McClusky, and A. A. Barka (2000), 1999 Izmit, Turkey Earthquake was no surprise, GSA Today, 10, 1-6.

Reimer, P. J., et al. (2004), IntCal04 terrestrial radiocarbon age calibration, $0-26$ cal kyr BP, Radiocarbon, 46, 1029-1058.

Rockwell, T., and M. Meghraoui (2003), Paleoseismology near the Sea of Marmara: Implications on the constancy of segment boundaries and multi-segment ruptures, paper presented at EGS-AGU-EUG Joint Assembly, Nice, France.

Sibson, R. H. (1985), Stopping of earthquake ruptures at dilational fault jogs, Nature, 316, 248-251.

Straub, C., H. Kahle, and C. Schindler (1997), GPS and geologic estimates of the tectonic activity in the Marmara Sea region, NW Anatolia, J. Geophys. Res., 102(B12), 27,587-27,602.

Stuiver, M., and P. D. Quay (1980), Changes in atmospheric carbon-14 attributed to a variable Sun, Science, 207, 11-19.

Stuiver, M., and P. J. Reimer (2005), Extended ${ }^{14} \mathrm{C}$ data base and revised CALIB $3.0{ }^{14} \mathrm{C}$ age calibration program, Radiocarbon, 35, 215-230.

Sugai, T., Y. Awata, S. Toda, Ö. Emre, A. Dogan, S. Ozalp, T. Haraguchi, H. Kinoshita, K. Takada, and M. Yamaguchi (2001), Paleoseismic investigation of the 1999 Düzce earthquake fault at Lake Efteni, North Anatolian fault system, Turkey, Annu. Rep. Active Fault Paleoearthquake Res. 1, Active Fault Res. Cent., Tsukuba, Japan.

Wallace, R. E. (1987), Grouping and migration of surface faulting and variation in slip rates on faults in the Great Basin province, Bull. Seismol. Soc. Am., 77, 868-877.

Wong, H. K., T. Luedmann, A. Ulug, and N. Gorur (1995), The Sea of Marmara: A plate boundary sea in an escape tectonic regime, Tectonophysics, 244(4), 231-250.

P. E. F. Collins, School of Engineering and Design, Brunel University, Uxbridge UB8 3PH, UK

G. D’Addezio, P. M. De Martini, N. Palyvos, D. Pantosti, and S. Pucci, Sismologia e Tettonofisica, Istituto Nazionale di Geofisica e Vulcanologia, Via di Vigna Murata 605, I-00143 Rome, Italy. (pantosti@ingv.it)

C. Zabci, Department of Geological Engineering, Faculty of Mines, Istanbul Technical University, Ayaza a Kampüsü, 80626 Maslak, Istanbul, Turkey. 